\title{
Surface velocity and mass balance of Livingston Island ice cap, Antarctica
}

\author{
B. Osmanoglu ${ }^{1,2}$, F. J. Navarro ${ }^{3}$, R. Hock ${ }^{1,4}$, M. Braun ${ }^{5}$, and M. I. Corcuera ${ }^{3}$ \\ ${ }^{1}$ Geophysical Institute, University of Alaska Fairbanks, P.O. Box 757320 Fairbanks, Alaska, 99775, USA \\ ${ }^{2}$ Biospheric Sciences Lab., USRA-NASA GSFC, Mail Stop 618.0, Greenbelt, MD, 20771, USA \\ ${ }^{3}$ Dept. Matemática Aplicada, ETSI de Telecomunicación, Universidad Politécnica de Madrid, Av. Complutense, 30, \\ 28040 Madrid, Spain \\ ${ }^{4}$ Department of Earth Sciences, Uppsala University, Geocentrum, Villavägen 16, 75236 Uppsala, Sweden \\ ${ }^{5}$ Institute of Geography, University of Erlangen, Kochstrasse 4/4, 91054 Erlangen, Germany
}

Correspondence to: B. Osmanoglu (batuhan.osmanoglu@ nasa.gov)

Received: 30 June 2013 - Published in The Cryosphere Discuss.: 26 August 2013

Revised: 26 July 2014 - Accepted: 8 August 2014 - Published: 8 October 2014

\begin{abstract}
The mass budget of the ice caps surrounding the Antarctica Peninsula and, in particular, the partitioning of its main components are poorly known. Here we approximate frontal ablation (i.e. the sum of mass losses by calving and submarine melt) and surface mass balance of the ice cap of Livingston Island, the second largest island in the South Shetland Islands archipelago, and analyse variations in surface velocity for the period 20072011. Velocities are obtained from feature tracking using 25 PALSAR-1 images, and used in conjunction with estimates of glacier ice thicknesses inferred from principles of glacier dynamics and ground-penetrating radar observations to estimate frontal ablation rates by a flux-gate approach. Glacier-wide surface mass-balance rates are approximated from in situ observations on two glaciers of the ice cap. Within the limitations of the large uncertainties mostly due to unknown ice thicknesses at the flux gates, we find that frontal ablation $\left(-509 \pm 263 \mathrm{Mt} \mathrm{yr}^{-1}\right.$, equivalent to $-0.73 \pm 0.38 \mathrm{~m}$ w.e. $\mathrm{yr}^{-1}$ over the ice cap area of $697 \mathrm{~km}^{2}$ ) and surface ablation $\left(-0.73 \pm 0.10 \mathrm{~m}\right.$ w.e. $\left.\mathrm{yr}^{-1}\right)$ contribute similar shares to total ablation $\left(-1.46 \pm 0.39 \mathrm{~m}\right.$ w.e. $\left.\mathrm{yr}^{-1}\right)$. Total mass change $\left(\delta M=-0.67 \pm 0.40 \mathrm{~m}\right.$ w.e. $\left.\mathrm{yr}^{-1}\right)$ is negative despite a slightly positive surface mass balance $\left(0.06 \pm 0.14 \mathrm{~m}\right.$ w.e. $\left.\mathrm{yr}^{-1}\right)$. We find large interannual and, for some basins, pronounced seasonal variations in surface velocities at the flux gates, with higher velocities in summer than in winter. Associated variations in frontal ablation (of $\sim 237 \mathrm{Mt} \mathrm{yr}^{-1} ;-0.34 \mathrm{~m}$ w.e. $\mathrm{yr}^{-1}$ ) highlight the importance
\end{abstract}

of taking into account the seasonality in ice velocities when computing frontal ablation with a flux-gate approach.

\section{Introduction}

According to the recent Fifth Assessment of the Intergovernmental Panel on Climate Change (IPCC, 2013), the mass losses from mountain glaciers and ice caps (henceforth referred to as glaciers) continue to be one of the largest contributors to sea-level rise, with a share of $27 \%$ of the sum of the estimated contributions over the period 1993-2010, larger than the combined contribution by the Antarctic and Greenland ice sheets of $21 \%$.

The glaciers surrounding the Antarctic mainland cover $18 \%$ of the global glacier area (Pfeffer et al., 2014), but their mass budget is not well understood. Shepherd et al. (2012) gave an estimate of the mass budget (1992-2011) for the entire Antarctic Peninsula of $-20 \pm 14 \mathrm{Gt} \mathrm{yr}^{-1}$, excluding glaciers peripheral to the Antarctic Peninsula. They pointed out that "the spatial sampling of mass fluctuations at the Antarctic Peninsula Ice Sheet is as present inadequate, particularly considering that it provides a significant component of the overall Antarctic Ice Sheet imbalance". Gardner et al. (2013) gave an estimate of $-6 \pm 10 \mathrm{Gt} \mathrm{yr}^{-1}$ for the mass budget of the glaciers of the Antarctic periphery during 2003-2009, which corresponds to $2 \%$ of global glacier wastage. In contrast, Hock et al. (2009) concluded that these 
glaciers made up $28 \%$ of the global estimate for the period 1961-2004, stressing the importance of further mass-balance studies in this region. In addition, the contribution of the Antarctic periphery has been projected to strongly increase during the 21 st century. Using a multi-model approach that encompasses 14 global climate models, Radić et al. (2013) estimated total contributions to sea-level rise from glaciers in the Antarctic periphery, over the period 2006-2100, of 21 and $28 \mathrm{~mm}$ sea level equivalent (SLE) for emission scenarios RCP4.5 and RCP8.5, respectively, which represent 14 and $13 \%$ of the projected total glacier contribution.

These projections (as all large-scale projections included in IPCC, 2013) are based exclusively on surface mass balance (Raper and Braithwaite, 2006; Radić and Hock, 2011; Marzeion et al., 2012; Slangen et al., 2012; Giesen and Oerlemans, 2013; Radić et al., 2013), thus leading to systematic underestimation of mass loss of tidewater glaciers, since frontal ablation is discarded. By frontal ablation we mean the loss of mass from the near-vertical calving fronts of the marine-terminating glaciers, including losses by calving, subaqueous melting, and subaerial melting and sublimation (Cogley et al., 2011). Frontal ablation is an important component of the total ablation of marine-terminating glaciers. The recent availability of a nearly complete worldwide inventory of the world's glaciers (Pfeffer et al., 2014) has revealed that $38 \%$ (by area) of them are marine-terminating, and this number increases to $98-99 \%$ for those in the Antarctic periphery (Gardner et al., 2013; Bliss et al., 2013). However, data regarding the partitioning of total glacier mass loss into its main components (surface mass balance and frontal ablation) are very scarce. Such estimates are crucial to understand the evolution of the mass balance in a region that has shown considerable regional warming (Steig and Orsi, 2013; Turner et al., 2013).

For the glaciers covering the islands off the western coast of the Antarctic Peninsula, some estimates of frontal ablation have recently been reported (Osmanoglu et al., 2013a; Navarro et al., 2013). Osmanoglu et al. (2013a) found large rates of frontal ablation on the neighbouring ice cap of King George Island ( $720 \pm 428 \mathrm{Mt} \mathrm{yr}^{-1}$, corresponding to $-0.64 \pm$ $0.38 \mathrm{~m}$ w.e. $\mathrm{yr}^{-1}$ over the ice cap's total area of $1127 \mathrm{~km}^{2}$ ), but insufficient data on surface mass balance were available to determine the relative importance of frontal ablation in the mass budget.

Here we estimate the mass budget of the ice cap on Livingston Island, the second largest island in the South Shetland Islands archipelago, located north-west of the tip of the Antarctic Peninsula (Fig. 1), for the period October 2007March 2011. We approximate surface mass balance and frontal ablation separately in order to quantify the relative shares of these components to total ablation. We adopt a fluxgate method to approximate frontal ablation by the ice discharge through defined flux gates close to the marine termini. Hence, the approach does not distinguish between the individual components of frontal ablation, which we assume consist mostly of calving and submarine melt. The flux-gate approach requires the knowledge of both ice velocities and ice thickness at given flux gates. Radar remote sensing data are used to derive ice velocities, which in turn are used to approximate ice thickness based on principles of glacier dynamics and calibrated against available ground-penetrating radar (GPR)-retrieved ice thickness. We also investigate the temporal variations in ice velocity, and their seasonality, at the defined flux gates. For our analyses we compile a new $50 \mathrm{~m} \times 50 \mathrm{~m}$ resolution digital elevation model (DEM) by merging existing data sets with satellite-derived elevations.

\section{Study area}

Livingston Island ice cap $\left(62^{\circ} 28^{\prime}-62^{\circ} 45^{\prime} \mathrm{S}, 59^{\circ} 49^{\prime}-\right.$ $60^{\circ} 59^{\prime} \mathrm{W}$ ) is about $60 \mathrm{~km}$ long and $30 \mathrm{~km}$ wide (Fig. 1). The glacier-covered area was $734 \mathrm{~km}^{2}$ in 1956 and shrunk by $4.3 \%$ during the period 1956-1996 to a glacierized area of $703 \mathrm{~km}^{2}$ in 1996 (Calvet et al., 1999). Our latest estimate using the 2004 outlines (unpublished data from Jaume Calvet and David García-Sellés) is $697 \mathrm{~km}^{2}$. Using data from the Randolph Glacier Inventory V3.2 (Pfeffer et al., 2014), Livingston Island area represents $23 \%$ of the area of the entire South Shetland Islands archipelago, while its ice volume, estimated using volume-area scaling as described in Bliss et al. (2013), is $25 \%$ of the ice volume of the whole archipelago. None of the marine termini of the ice cap are floating. The highest elevation on Livingston Island reaches above $1700 \mathrm{~m}$, in the Friesland Massif, in the south-eastern part of the island, while the island has an average elevation of about $300 \mathrm{~m}$ a.s.l.

The annual average temperature at Juan Carlos I Station (12 m a.s.l., Fig. 1) between 1988 and 2011 is $-0.9^{\circ} \mathrm{C}$, with average summer (DJF) and winter (JJA) temperatures of 2.4 and $-4.4{ }^{\circ} \mathrm{C}$, respectively. The cloudiness is high, with an average of sixth-eighths, and consequently sunshine duration is short, averaging $2 \mathrm{~h} \mathrm{day}^{-1}$ during summer and spring, though the cloud-free days during these seasons show high solar irradiance. The average relative humidity is above $80 \%$ (unpublished data from Agencia Estatal de Meteorología, AEMET).

Glacier-wide mass-balance estimates are only available for glaciers on the Hurd Peninsula (Fig. 2). Molina et al. (2007) estimated a geodetic mass balance of $-0.23 \pm$ $0.10 \mathrm{~m}$ w.e. $\mathrm{yr}^{-1}$ averaged over the period 1957-2000 for the ensemble Hurd-Johnsons (main glacier basins of Hurd Peninsula). The mass-balance estimates for the following decade show that the mass losses of Hurd (landterminating, $4.03 \mathrm{~km}^{2}$ ) and Johnsons (tidewater, $5.36 \mathrm{~km}^{2}$ ) glaciers have decelerated compared to the average values for 1957-2000. The equivalent average geodetic mass balances during 2001-2011 were $-0.15 \pm 0.10$ and $-0.09 \pm$ $0.11 \mathrm{~m} w . e . \mathrm{yr}^{-1}$ for Hurd and Johnsons, respectively, including $-0.14 \pm 0.04 \mathrm{mw}$.e. $\mathrm{yr}^{-1}$ of equivalent specific balance for frontal ablation of Johnsons, estimated by 


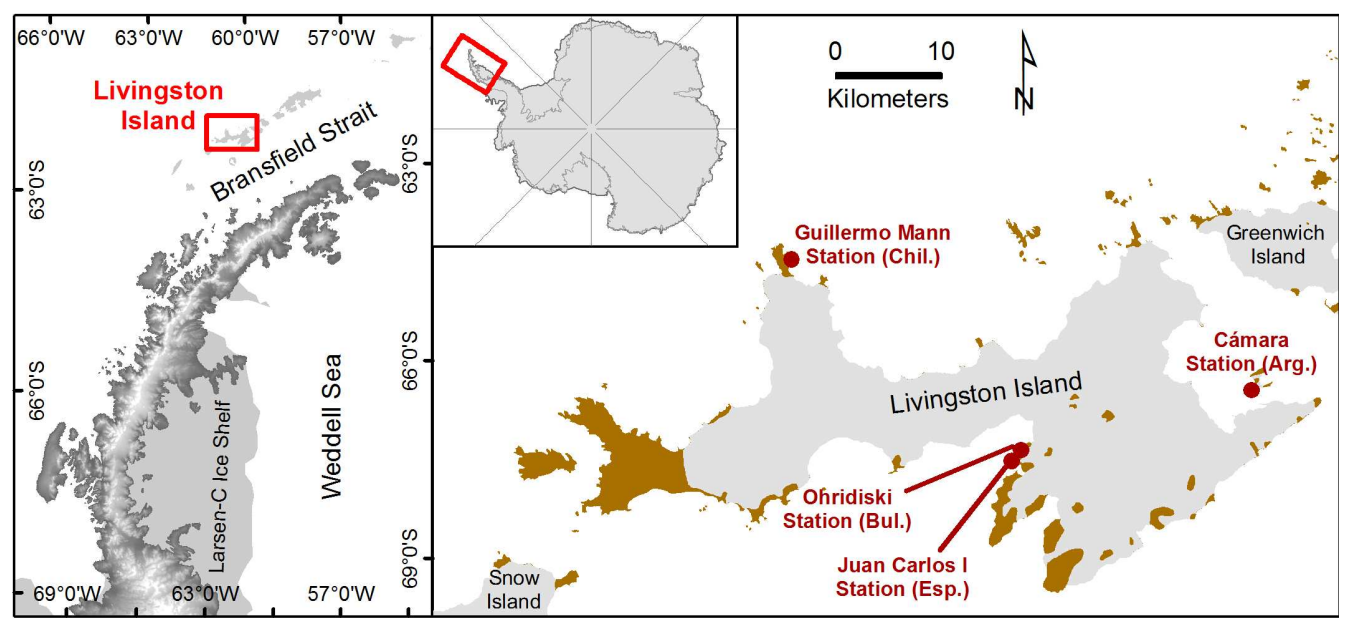

Figure 1. Location of Livingston Island, to the north-west of the tip of the Antarctic Peninsula. Brown denotes ice-free terrain, while grey is used for glacierized areas. Red dots mark the locations of research stations. Map base: SCAR Antarctic Digital Database, version 6.0; MOA coastline of Antarctica, NSIDC.

Navarro et al. (2013) for the period 2005-2008. The mean winter, summer and annual surface mass balances and the equilibrium line altitude (ELA) for the mass-balance years $2000 / 2001-2010 / 2011$ were $B_{\mathrm{w}}=0.62 \pm 0.16, B_{\mathrm{s}}=$ $-0.77 \pm 0.33, B_{\mathrm{a}}=-0.15 \pm 0.44 \mathrm{~m}$ w.e. $\mathrm{yr}^{-1}, \mathrm{ELA}=222 \pm$ $67 \mathrm{~m}$ for Hurd Glacier, and $B_{\mathrm{w}}=0.76 \pm 0.18, B_{\mathrm{s}}=-0.71 \pm$ $0.24, B_{\mathrm{a}}=0.05 \pm 0.30 \mathrm{~m}$ w.e. $\mathrm{yr}^{-1}, \mathrm{ELA}=187 \pm 37 \mathrm{~m}$ for Johnsons Glacier (Navarro et al., 2013). The uncertainties given are the standard deviations of the 10-year measurements. The errors of the individual annual or seasonal surface balances are much smaller, of the order of $\pm 0.10 \mathrm{~m}$ w.e. $\mathrm{yr}^{-1}$ for the surface balances, and $\pm 10 \mathrm{~m}$ for the equilibrium line altitude estimates. The standard deviations show that the largest interannual variability of the surface mass balance corresponds to the summer balance, which is mostly a consequence of the large interannual variability of the summer temperature record (Navarro et al., 2013). The landterminating Hurd Glacier shows, for all variables, a larger interannual variability than the marine-terminating Johnsons Glacier. The latter shows a higher surface mass balance and a lower equilibrium line altitude.

Jonsell et al. (2012) applied a distributed temperatureradiation index melt model calibrated against automatic weather station and in situ surface mass-balance data from Hurd Peninsula glaciers, revealing a high sensitivity of the mass balance of the ice cap to climate change. They showed that a $0.5{ }^{\circ} \mathrm{C}$ temperature increase results in $56 \%$ higher melt rates, which is mainly an effect of the on-glacier summer average temperatures being close to $0^{\circ} \mathrm{C}$. In situ ice velocity measurements are available on Hurd Peninsula (Ximenis et al., 1999; Otero, 2008; Otero et al., 2010), and ice thickness retrieved from GPR measurements are available for certain zones of the island (see details in Sect. 3). A summary of other previous glaciological studies on the

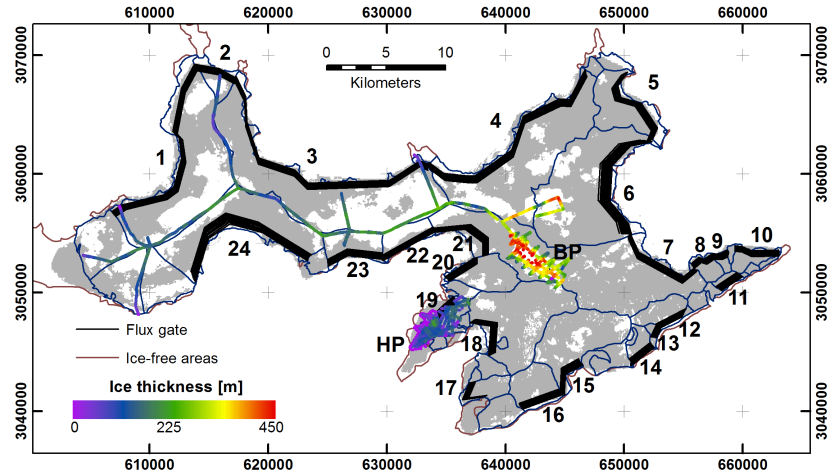

Figure 2. Livingston Island glacier basins according to Bliss et al. (2013). Numbers indicate the basins analysed in this study. Grey shading marks the area for which ice velocities could be derived from SAR data. Thick black lines denote flux gates used for computing ice discharge. Ice thicknesses obtained from GPR measurements are shown in colour. HP denotes Hurd Peninsula, and BP Bowles Plateau. The brown line indicates the coastline of the icefree areas.

island and the Antarctic Peninsula region can be found in Navarro et al. (2013).

\section{Data}

\subsection{SAR imagery}

Synthetic aperture radar (SAR) data were used to derive surface ice velocities and to compile a new DEM for the ice cap. Data from two sources were included: (1) time series from the PALSAR-1 imaging system on board the Japanese Advanced Land Observing Satellite (ALOS-1) satellite (Rosenqvist et al., 2007) and (2) a bistatic image 
Table 1. SAR imagery used in this study.

\begin{tabular}{cccl}
\hline Satellite & Track & Row & Date \\
\hline ALOS & 125 & 5890 & Mar-15-2011 \\
ALOS & 125 & 5890 & Jan-28-2011 \\
ALOS & 125 & 5890 & Oct-28-2010 \\
ALOS & 125 & 5890 & Jan-25-2010 \\
ALOS & 125 & 5890 & Dec-10-2010 \\
ALOS & 125 & 5890 & Oct-25-2009 \\
ALOS & 125 & 5890 & Jul-25-2009 \\
ALOS & 125 & 5890 & Mar-09-2009 \\
ALOS & 125 & 5890 & Jan-22-2009 \\
ALOS & 125 & 5890 & Dec-07-2008 \\
ALOS & 125 & 5890 & Oct-22-2008 \\
ALOS & 125 & 5890 & Jun-06-2008 \\
ALOS & 125 & 5890 & Apr-21-2008 \\
ALOS & 125 & 5890 & Dec-05-2007 \\
ALOS & 125 & 5890 & Oct-20-2007 \\
ALOS & 124 & 5890 & Jan-11-2011 \\
ALOS & 124 & 5890 & Nov-26-2010 \\
ALOS & 124 & 5890 & Oct-11-2010 \\
ALOS & 124 & 5890 & Feb-23-2010 \\
ALOS & 124 & 5890 & Jam-08-2010 \\
ALOS & 124 & 5890 & Nov-23-2009 \\
ALOS & 124 & 5890 & Ocy-05-2008 \\
ALOS & 124 & 5890 & May-20-2008 \\
ALOS & 124 & 5890 & Apr-04-2008 \\
ALOS & 124 & 5890 & Feb-18-2008 \\
\hline TanDEM-X & 159 & 13 & Mar-18-2012 \\
\hline & & & \\
\hline
\end{tabular}

pair from the TerraSAR-X and TanDEM-X satellite mission (Krieger et al., 2007; Mittermayer et al., 2008). The imagery used is listed in Table 1.

PALSAR-1 provides L-band (1270 MHz) signals and was operational during 2006-2011. We used two parallel tracks (124 and 125) covering the entire ice cap, which provided a total of 25 images between October 2007 and March 2011. All images were collected in fine-beam single polarization mode, which gives a ground resolution of about $9 \mathrm{~m} \times 5 \mathrm{~m}$. The images have a swath width of $\sim 70 \mathrm{~km}$ in the range direction.

The bistatic TanDEM-X pair was acquired by TerraSAR-X and TanDEM-X satellites simultaneously, generating highquality interferometric data by removing the effects of temporal decorrelation. These images have a ground resolution of about $3 \mathrm{~m} \times 3 \mathrm{~m}$ and cover an area of about $30 \mathrm{~km} \times 30 \mathrm{~km}$. The X-band $(9.65 \mathrm{GHz})$ signal penetrates into the snow and ice. The penetration depth depends on properties like liquid water content, density, crystal size and layering of the snow/firn column, and may reach $10 \mathrm{~m}$ in dry snow but only a few centimetres under wet snow conditions (Rees, 2006). The TanDEM-X acquisition of 18 March 2012 occurred at the transition from late summer to cooler winter conditions. However, the TanDEM-X amplitude image indicates still wet snow conditions (low backscatter) and some bare ice areas close to the glacier front. Hence, we consider the penetration depth for this case minimal, thus allowing us to derive accurate DEMs from the data.

\subsection{Digital elevation model (DEM)}

The only topographic maps available covering the entire Livingston Island are the $1: 200000$ map by DOS (1968), based on aerial photos taken in 1957, and the $1: 100000$ map by SGE (1997), based on Système Pour l'Observation de la Terre (SPOT) images of 1991 and 1996 (Korona et al., 2009). An accurate high-resolution DEM is not available. Therefore we compiled a new DEM for Livingston Island with $50 \mathrm{~m} \times 50 \mathrm{~m}$ grid cells (Fig. 3) based on

1. the Radarsat Antarctic Mapping Project (RAMP) DEM (Liu, 2001);

2. radargrammetry using PALSAR-1 data;

3. TanDEM-X bistatic interferometry;

4. the Advanced Spaceborne Thermal Emission and Reflection Radiometer (ASTER) Global DEM v.2;

5. the Ice, Cloud and Land Elevation Satellite (ICESat) elevation profiles, level 1B global elevation data (GLA06) obtained from the National Snow and Ice Data Center (NSIDC).

The RAMP DEM covers the entire island with $200 \mathrm{~m} \times 200 \mathrm{~m}$ grid cell resolution, which we resample to $50 \mathrm{~m} \times 50 \mathrm{~m}$ (Fig. 3a). First, the RAMP DEM was sharpened using a SAR intensity image. The intensities of a SAR interferogram generated from PALSAR-1 images were used to estimate local slopes (Eineder, 2003). These slope measurements are one-dimensional and cannot be used to infer topography. However, they can be used to sharpen an existing DEM by scaling the elevation values using relative slope information. One-dimensional slope information was then scaled to the range between 0.75 and 1.25 , and multiplied by the RAMP DEM to superimpose the obtained structure from the intensity image to the RAMP DEM without altering the histogram of original elevation values (Fig. 3b). Even though the sharpened RAMP DEM has smaller scale variability, statistically its misfit to ICESat elevations did not change after this operation. Mean and standard deviation of the misfit for RAMP and sharpened RAMP DEMs show little difference (RAMP: $148 \pm 74 \mathrm{~m}$; sharpened RAMP: $139 \pm 67 \mathrm{~m}$ ). For comparison, the ICESat laser footprint is $\sim 60 \mathrm{~m}$, separated by $\sim 170 \mathrm{~m}$ along the ground track (Fig. 3c).

Second, additional higher quality partial DEMs for the ice cap were generated. Radargrammetry was used to derive a $\sim 160 \mathrm{~m}$ resolution DEM for the eastern half of the ice cap using PALSAR-1 data from two parallel tracks (Fig. 3d). 

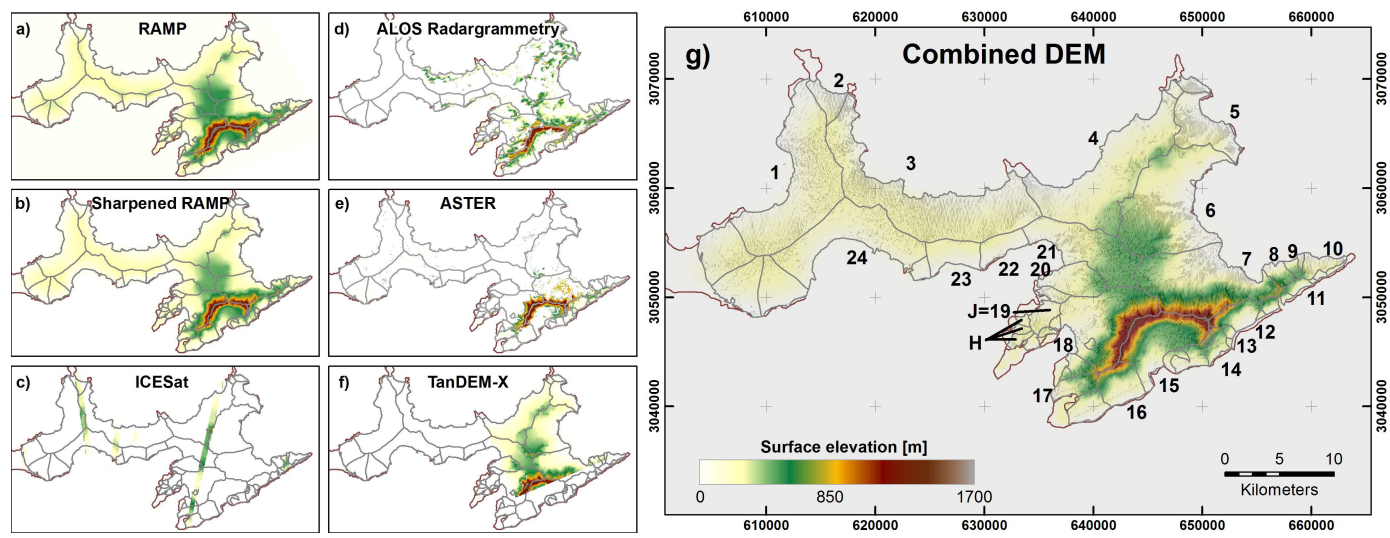

Figure 3. Digital elevation data used in this analysis. There are 792 ICESat data points distributed among five different satellite tracks. Radargrammetry and ASTER data provide elevations outside the TanDEM-X coverage. Hurd Glacier and Johnsons Glacier, where surface mass-balance observations are available, are labelled as $\mathrm{H}$ and $\mathrm{J}$, respectively. The brown line indicates the coastline of the ice-free areas.

PALSAR-1 data provided the two different look angles necessary for radargrammetry, while the relatively short 16-day baseline limited the amount of surface change due to glacier motion and snow cover between the two images (Balz et al., 2009). In addition, a higher resolution (10 m) DEM was generated from bistatic TanDEM-X interferometry (Fig. 3f). The unwrapping was done using a modified version of the SNAPHU unwrapping software, capable of multigrid unwrapping (Chen and Zebker, 2001). The entire InSAR processing was performed at full resolution, though the final DEM was resampled to a $10 \mathrm{~m} \times 10 \mathrm{~m}$ grid to increase redundancy and reduce gaps due to radar shadows. The DEM is restricted to the parts in the north-east of the ice cap that are covered by the satellite scene. Further, we used the $30 \mathrm{~m}$ resolution ASTER GDEM v.2 data, but the data are heavily affected by cloud cover. To ensure sufficient quality, we only included pixels with three or more available observations, which reduced the coverage mostly to the south-eastern part of the ice cap (Fig. 3e).

A first-order polynomial plane was removed from all DEMs. All DEMs were best-fitted to the ICESat data, and finally resampled to $50 \mathrm{~m}$ pixel spacing before merging. The final elevation $z$ for each pixel was obtained by taking weighted averages of the available data. The weights were selected adaptively as a function of the expected error and number of neighbouring points:

$z=\frac{\sum_{i=1}^{5} w_{\sigma}^{i} w_{\mathrm{n}}^{i} z^{i}}{\sum_{i=1}^{5} w_{\sigma}^{i} w_{\mathrm{n}}^{i}}$

where $i$ denotes five different data sets (sharpened RAMP, ICESat, radargrammetry, ASTER and TanDEM-X), $w_{\sigma}$ denotes weighting based on expected error, and $w_{\mathrm{n}}$ is weighting based on the distance to the nearest neighbour. The expected root-mean-square error (RMSE) for the ASTER GDEM depends on topography and number of observations available, ranging from 3 to $50 \mathrm{~m}$ (Reuter et al., 2009; Hirt et al., 2010;
Hengl and Reuter, 2011). The TanDEM-X DEM is expected to provide $10 \mathrm{~m}$ absolute and 2-4 m relative vertical accuracy (Gonzalez et al., 2010). ICESat altimeter data are accurate to $\sim 0.3 \mathrm{~m}$ in the vertical (Magruder et al., 2007). The accuracy of radargrammetry changes with topography, accuracy of correlation and orbit accuracy, and is expected to be of the order of 10-50 m (Balik et al., 2004; Balz et al., 2009, 2013). The RAMP DEM has a spatially variable error, which increases with surface slope. The DEM is expected to be accurate to $30 \mathrm{~m}$ in the vertical (Bamber and Gomez-Dans, 2005). The quality of the DEMs was estimated by analysing the RMSE according to the most accurate data: the ICESat data. All measurements, including the ICESat data, were geocoded using the same $50 \mathrm{~m}$ grid for easy comparison. In some cases where multiple measurement points fell into the same grid cell, the points were averaged thus reducing the noise. The RMSE was then calculated as

$\operatorname{RMSE}_{z}=\sqrt{\frac{1}{N} \sum_{p=1}^{N}\left(z_{p}^{i}-z_{p}^{\text {ICESat }}\right)^{2}}$,

where $\mathrm{RMSE}_{z}$ is the root-mean-square error for elevation, $N$ is the number of points and the superscript $i$ is used to indicate the different elevation models: sharpened RAMP, radargrammetry, ASTER and TanDEM-X. The RMSE for the different DEMs compared with ICESat were 137, 228, 417, $130 \mathrm{~m}$ for sharpened RAMP, radargrammetry, ASTER GDEM and TanDEM-X, respectively. These deviations not only reflect differences in elevation between data sets but also the correlation between number of samples available for each data set; therefore the data sets, with the lowest number of overlaps with ICESat data show the largest deviations. There were 792, 144, 51 and 259 points available for comparisons between ICESat and the other four DEMs (sharpened RAMP, radargrammetry, ASTER GDEM and TanDEM-X, respectively). For this analysis we gave equal weighting to ICESat and TanDEM-X DEM (SD $\sim 5 \mathrm{~m})$, as well as 
ASTER GDEM and RAMP (SD $\sim 25 \mathrm{~m}$ ). The radargrammetry had the lowest weight $(\mathrm{SD} \sim 50 \mathrm{~m})$. The combined DEM is shown in Fig. 3g, and the standard deviation of errors relative to 792 ICESat measurements was $121 \mathrm{~m}$.

Given the large RMSE between some of the individual DEMs and ICESat data, and for the sake of homogeneity, we investigated whether it would be better to use one of the better quality DEMs covering the entire island, in particular the sharpened RAMP DEM. This, however, resulted in a slight worsening (by $5 \%$ ) of the root-mean-square (rms) misfits between the computed and observed ice thickness. Moreover, the standard deviation of errors relative to ICESat measurements, of $121 \mathrm{~m}$ for the combined DEM, is lower than that of the sharpened RAMP DEM (146 m). Consequently, we decided to adhere to our combined DEM. Nevertheless, for comparison we also performed all computations for the sharpened RAMP DEM, resulting in only small changes in the results for total frontal ablation, as will be discussed later.

\subsection{In situ surface velocities}

In situ glacier surface velocity measurements at Livingston Island are only available on Hurd Peninsula (Ximenis et al., 1999; Otero, 2008; Otero et al., 2010), where a net of about 50 stakes distributed across Johnsons and Hurd glaciers has been measured, using differential GPS (theodolite for the earliest measurements) several times per summer since 1994 (Johnsons) and 2001 (Hurd). Johnsons Glacier, a tidewater glacier (19 in Fig. 2), has velocities increasing from zero at the ice divides to typical year-averaged values close to $50 \mathrm{~m} \mathrm{yr}^{-1}$ in the fastest part of its calving front, but for most of its area the velocities are below $10 \mathrm{~m} \mathrm{yr}^{-1}$. Johnsons' measured velocities close to its calving front, together with dynamical modelling results, have been used to derive the only local estimate of frontal ablation so far available for Livingston Island (Navarro et al., 2013). Hurd Glacier, which terminates on land, has lower velocities, with observed yearaveraged values always below $5 \mathrm{~m} \mathrm{yr}^{-1}$. The maximum velocities are observed in the upper ablation area, and strongly decrease near the glacier snout, which has been suggested to be frozen to the bed based on geomorphological analyses and GPR studies (Molina et al., 2007; Navarro et al., 2009).

\subsection{Surface mass-balance and frontal ablation estimates}

Aside from some observations on Rotch Dome (westernmost part of the ice cap) during 1971-1974 (Orheim and Govorukha., 1982), the surface mass balance of the ice cap has only been studied on Hurd Peninsula (Ximenis et al., 1999; Navarro et al., 2013). The latter study includes massbalance profiles (winter, summer, and annual) averaged over the period 2002-2011 for Johnsons (tidewater) and Hurd (land-terminating) glaciers.

Previous estimates of frontal ablation from Livingston Island glaciers are limited to Johnsons Glacier, for which
Navarro et al. (2013) indicate that mass losses by frontal ablation over the period April 2006-March 2008 represent only $16 \%$ of the glacier's total annual ablation, the remaining portion originating from surface ablation (assuming that basal melting and internal accumulation are negligible). However, this glacier has a very particular setting, with a very shallow pro-glacial bay (just a few metres depth), a nearly flat bed in the area close to the calving front, and moderate frontal velocities (maximum values of the order of $50 \mathrm{~m} \mathrm{yr}^{-1}$ ), implying a small flux of ice into the ocean.

\subsection{Ice thickness}

Ice-thickness data are only available for limited parts of the ice cap. These were retrieved from $20 \mathrm{MHz}$ ground-based GPR measurements carried out along the main ice divides of the western part of the island in December 2000, and on Bowles Plateau (BP in Fig. 2), which is the accumulation area of Perunika Glacier (21 in Fig. 2), in December 2006. The data are described in Macheret et al. (2009). Typical thickness under the western divides is $\sim 150 \mathrm{~m}$, reaching maxima of $\sim 200 \mathrm{~m}$, and the average thickness under Bowles Plateau is $\sim 265 \mathrm{~m}$, with maximum thicknesses of $500 \mathrm{~m}$. GPR measurements on Hurd Peninsula glaciers carried out at different radar frequencies and various dates are described in Navarro et al. (2009), and show an average thickness of $\sim 94 \mathrm{~m}$ and maximum values of $\sim 200 \mathrm{~m}$. Higher frequency (200 MHz) GPR measurements have allowed for the estimation of typical firn thickness on the ice cap. For the accumulation areas at lower elevations (below 300-400 m), where summer melting is frequent and the firn compaction is more intense, the firn thickness rarely exceeds $15 \mathrm{~m}$, while for the accumulation areas at higher elevations, the firn thickness reaches up to 30-35 m (Macheret et al., 2009; Navarro et al., 2009).

\section{Methods}

\subsection{Surface velocities}

Feature tracking was used to obtain glacier surface velocities from PALSAR-1 intensity images (Gray et al., 1998; Strozzi et al., 2002, 2008; Werner et al., 2005). We preferred feature tracking, rather than coherence tracking, because of the large extent of incoherent areas in the available imagery (Strozzi et al., 2002). In this study, inconsistent velocity measurements were masked out using a spatial variance filter, such that surface velocity measurements that have a Fisher distance of $80 \mathrm{~m} \mathrm{yr}^{-1}$ (with a constant expected error of $4 \mathrm{~m} \mathrm{yr}^{-1}$ ) or above compared to their neighbours are discarded (Osmanoglu et al., 2011).

The 25 ALOS PALSAR-1 scenes acquired between October 2007 and March 2011 from tracks 124 and 125 were grouped to form short paired temporal baselines to reduce measurement errors (Osmanoglu et al., 2013b). However, 
due to acquisition gaps, especially over austral winter months, there are some pairs with longer baselines. Surface velocity time series can be constructed with an inversion similar to small baselines analysis (Berardino et al., 2002; Lanari et al., 2007). However, the poor velocity estimates for pairs with long temporal baselines do not allow for construction of a redundant network, where each scene is connected with more than one pair. Therefore, the velocity time series were constructed based on the measured displacements for each pair.

In addition to averaging data from multiple pairs to increase the coverage and statistical significance of the annual surface velocity field, we also investigated the temporal variations in the surface velocities at the flux gates, and analysed their seasonality and their impact on resulting frontal ablation estimates for all calculated flux gates, as discussed below.

\subsection{Temporal variations in surface velocities}

To analyse the temporal variations in surface velocities at the flux gates, we computed average detrended velocities at the given flux gates. We did not attempt to estimate trends in surface velocity, because our velocity measurement period is too short, and, if detected, these would likely be associated with the increase in velocity experienced as the glacier ice approaches the calving front, and thus do not represent a change in velocity with time at a given spatial location (Eulerian velocity) but instead a change in velocity of a given particle with time (Lagrangian velocity). Velocities were computed for all available periods spanning 46 to 368 days. The magnitude of the temporal variations in surface velocities was approximated as the standard deviation of the computed velocities. The flux-gate length, average ice thickness and standard deviation of detrended surface velocities were used to calculate the $1 \sigma$ contribution of temporal variations in velocity to the estimated ice flux.

Seasonal variations were modelled by fitting a periodic signal (cosine) to the weighted observations of detrended velocities. The inverse of temporal baselines were selected as weights such that the shortest possible temporal baseline (of 46 days) has a weight of 1 , while longer baselines have proportionally lower weights. The periodic signal does not account for interannual variations, yet it provides a measure of the seasonal amplitude and timing over the study period.

\subsection{Frontal ablation}

Frontal ablation is approximated by the ice flux perpendicular to a theoretical surface ("flux gate") close to the glacier terminus. Flux gates were only defined for marine terminating glaciers where the ice velocities at the flux gates exceeded $20 \mathrm{~m} \mathrm{yr}^{-1}$ (Fig. 2). For the remaining glaciers, frontal ablation was assumed negligible. For robust estimation of the ice discharge of each computed tidewater glacier, 10 parallel flux gates at intervals of $\sim 50 \mathrm{~m}$ were defined with the lowest gate as close as possible to the calving front, roughly between 100 and $600 \mathrm{~m}$ up-glacier from the front. Ice discharges for all 10 flux gates were calculated individually and averaged to obtain our final estimate. Deviation of each flux gate's estimate from the mean was calculated and flux gates with deviations higher than $20 \%$ of the mean were discarded. On average, 7.5 flux gates were used per glacier. Flow directions were computed from feature tracking.

Following Rignot (1996) and Osmanoglu et al. (2013a), we derive the ice flux $q$ for each computed grid cell along a glacier's flux gate from surface velocities by

$q=H \gamma u_{\mathrm{sfc}}$,

where $H$ is ice thickness and $\gamma$ is the ratio between thickness-averaged and horizontal surface velocity $u_{\text {sfc }}$. For glacier deformation in simple shear (as assumed here), $\gamma$ is bounded between 0.8 , if the motion is entirely by internal deformation, and 1 , if the motion is entirely by slip (Cuffey and Paterson, 2010). In the absence of additional information on the vertically averaged velocity, here we assume $\gamma=0.9$. Note, additionally, that we will later tune a parameter weighting the contributions of internal deformation and basal sliding to the glacier surface velocity. $u_{\mathrm{sfc}}$ and $H$ are a function of position along the flux gate. The ice discharge $D$ is then defined as the integral of ice flux perpendicular to the flux gate over the length $L$ of the flux gate:

$D=\int_{0}^{L} q \rho_{\text {ice }} \mathrm{d} l$,

where $\rho_{\text {ice }}$ is the density of ice $\left(900 \mathrm{~kg} \mathrm{~m}^{-3}\right)$. Note that we are here considering the vertically averaged density at flux gates, which are located at the lowest elevations of the ablation area. Consequently, during summertime the column is made of ice, while in winter the ice column is topped by a snow layer of at most $2 \mathrm{~m}$ of snow (an upper bound for the winter accumulation). The average thickness at the flux gates (weighted by the flux-gate length) is $142 \mathrm{~m}$. Assuming $2 \mathrm{~m}$ of snow in wintertime, and 900 and $500 \mathrm{~kg} \mathrm{~m}^{-3}$ as densities for ice and snow, respectively, the average density of the icesnow winter column would be $894 \mathrm{~kg} \mathrm{~m}^{-3}$, while in summer it would be $900 \mathrm{~kg} \mathrm{~m}^{-3}$. The difference from the standard value for ice $\left(900 \mathrm{~kg} \mathrm{~m}^{-3}\right)$, zero in summer and lower than $0.7 \%$ in winter, is therefore insignificant. Using $900 \mathrm{~kg} \mathrm{~m}^{-3}$ additionally allows for direct comparison with the ice discharge values found in the literature.

Ice discharge through the flux gates as computed by Eq. (4) is assumed to represent the mass lost through frontal ablation. Hence, we assume that the positions of the calving fronts have remained stationary during the measurement period, and therefore mass changes due to terminus retreat/advance do not need to be considered. In our case, this is an admissible assumption because, though fluctuations of the ice fronts 
have indeed occurred, most calving front positions have experienced little change during the last decade. Frontal ablation is given in units of $\mathrm{Mt} \mathrm{yr}^{-1}$ and for comparison with the surface mass-balance results (given in specific units) converted to $\mathrm{m}$ w.e. $\mathrm{yr}^{-1}$. Note that ice discharge is positive (Eq. 4) but we report frontal ablation $A_{\mathrm{f}}$ as negative values (i.e. $A_{\mathrm{f}}=-D$; Cogley et al., 2011).

\subsection{Ice thickness}

Ice-thickness observations are not available for any of the flux gates except for Johnsons Glacier (19 in Fig. 2). Therefore, we estimate the ice thickness at the flux gates from the surface velocity field following the method proposed by Rignot (1996) for ocean-terminating glaciers and also applied on King George Island by Osmanoglu et al. (2013a):

$$
\begin{aligned}
u_{\mathrm{sfc}} & =(1-f)\left(\left[\frac{\tau_{\mathrm{d}}}{B}\right]^{n} E H\right)+f\left(\frac{\tau_{\mathrm{d}}}{R}\right)^{m}, \\
\tau_{\mathrm{d}} & =\rho_{\text {ice }} g H \sin \alpha,
\end{aligned}
$$

where $u_{\mathrm{sfc}}$ is the surface velocity obtained from feature tracking, $f$ is an adjustable parameter between 0 and 1 setting the amount of sliding ( $f=0$, no sliding; $f=1$, pure sliding), $n$ is the Glen's flow law parameter, $\tau_{\mathrm{d}}$ is the gravitational driving stress, $B$ is the column-averaged stiffness parameter in Glen's flow law, $E$ is the flow law enhancement factor, $H$ is the estimated ice thickness, $R$ is a factor including the effects of bed roughness, and $m$ is the Weertman's sliding law parameter. In Eq. (6), $g$ is gravity, and $\alpha$ is the surface slope. The deformation component of Eq. (5) assumes deformation by simple shear, i.e. it does not include the effect of longitudinal stress gradients. In contrast to Rignot (1996), we treat $E$ as an adjustable parameter rather than a constant. Typical values for $E$ are in the range $0.5-10$; however values outside this range have also been reported (Greve and Blatter, 2009). For this analysis we calculate $B$ based on ice temperature defined by an Arrhenius relationship $\left(-3^{\circ} \mathrm{C}\right.$, $B=231.866 \mathrm{kPa} \mathrm{yr}^{1 / 3}$ ), while we set $R$ as $4 \mathrm{kPa} \mathrm{m}^{-1 / 2} \mathrm{yr}^{1 / 2}$ (Rignot, 1996; Greve and Blatter, 2009; Cuffey and Paterson, 2010). The $m$ and $n$ parameters are set to 2 and 3, respectively, while a truncated-Newton iterative optimization routine is used to find the values of $f$ and $E$ that minimize the misfit between the available ice-thickness data (Fig. 2) and the ice thickness computed using Eq. (5).

In order to improve the fit, we separated the surface velocity fields into glacier regions of slow $\left(0-50 \mathrm{~m} \mathrm{yr}^{-1}\right)$, medium $\left(50-100 \mathrm{~m} \mathrm{yr}^{-1}\right)$ and fast $\left(>100 \mathrm{~m} \mathrm{yr}^{-1}\right.$ ) flow speeds, and fitted Eq. (5) for each region separately. Thus allowing for the possibility of having different material responses (through the enhancement factor $E$ ) and a different fractioning of the motion into internal deformation and basal slip (through the sliding parameter $f$ ) for the various zones, according to their distinct dynamical regime, substantially improved the misfit between computed and observed ice thicknesses, as discussed in Sect. 6.1. We found optimized values of
$E=0.57,0.19,8.91$ for slow/medium/fast flow, respectively, and $f=0$ in all cases. We note that for all three flow classes the value of $f$ obtained from optimizing $f$ and $E$ in tandem is unexpectedly low. It is likely that the enhancement factor $E$ at least partially compensates for the inability of the model to determine the ratio of deformation and sliding correctly. We adhere to the values of $f$ and $E$ derived from the optimization since they generate the best agreement between modelled and observed ice thicknesses but we investigate the sensitivity of $f$ and $E$ in Sect. 6.2.

\subsection{Surface mass balance}

Since detailed in situ surface mass-balance measurements are available for the land-terminating Hurd Glacier and the marine-terminating Johnsons Glacier, but nowhere else on the island, we approximate ice-cap-wide annual surface mass balance as follows. For both glaciers we determine linear summer balance gradients by regressing specific summer surface balances averaged over $20 \mathrm{~m}$ altitude bands vs. altitude for the mass-balance years 2008-2011 (approximately overlapping with the time span of our frontal ablation estimates) and apply them to the hypsometry of the entire ice cap (Fig. 4). We apply Johnsons Glacier's gradient to all tidewater basins ( $96.8 \%$ of total area), and Hurd Glacier's gradient to all land-terminating basins (3.2\%) assuming that these gradients are representative of the entire ice cap. For elevations where the gradient yields positive summer balances we assume $0 \mathrm{~m}$ w.e. $\mathrm{yr}^{-1}$.

We use the same approach for computing glacier-wide winter balances, but we assume that the winter balance remains constant above $600 \mathrm{~m}$ a.s.l. Altitudes above $600 \mathrm{~m}$ correspond to mountain areas (mostly to the Friesland Massif, reaching $1700 \mathrm{~m}$ ), which occupy a limited planar area of $\sim 6.3 \%$ of the ice cap. As a sensitivity test we also computed the winter balance where the gradient of winter surface mass balance vs. elevation was applied for the entire elevation range. We found negligible differences in results between both methods.

\subsection{Error analysis}

Uncertainties in our frontal ablation estimates stem mainly from errors in (1) derived surface velocities from feature tracking of PALSAR-1 images; (2) conversion of surface velocity to thickness-averaged velocity; (3) inference of ice thickness from thickness-averaged velocity and surface slope, including assumptions of the physical model and of the model parameter values; and (4) selection of flux gates. All error sources except for the latter can be quantified by comparing the estimated ice thickness with the available measurements, since errors in computed ice thickness include any errors due to (1)-(3) (see Eq. 5). Hence, we approximate the errors in frontal ablation from Eqs. (3) and (4), assuming that the ice thickness encompasses all errors, which 

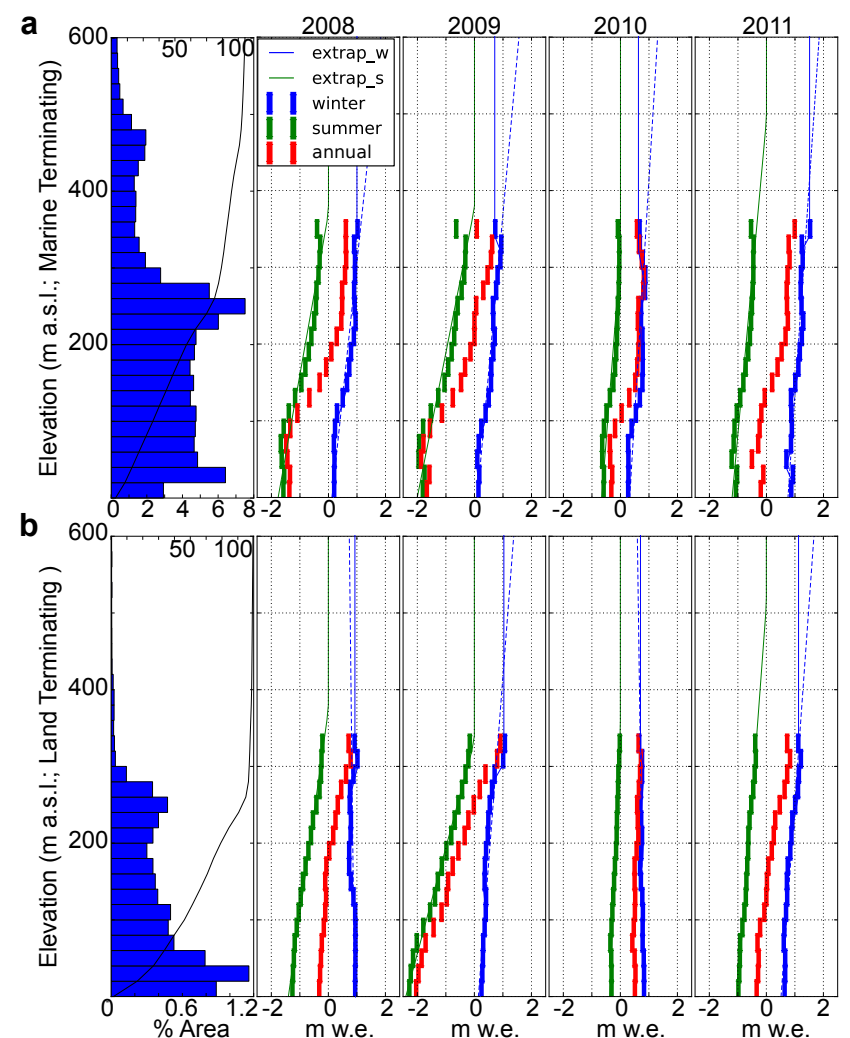

Figure 4. Winter, summer and annual mass-balance profiles from Johnsons (a) and Hurd glaciers (b) for the mass-balance years $2007 / 2008$ to $2010 / 2011$ used to determine the surface mass balance of the entire ice cap. The area-altitude distribution for the whole Livingston Island ice cap is shown for $20 \mathrm{~m}$ elevation bands (blue bars) and cumulative (black line), for marine-terminating (a) and land-terminating (b) basins. Thinner lines (extrap_w and extrap_s) show the extrapolation of the profiles beyond the elevations where observations are available. For the winter balance, two approaches (solid and dashed blue line) were compared. The profiles are based on measurements taken in late November/early December (winter balance) and late February/early March (summer balance). The former measurements coincide well with the start of the melting season, but for the summer balances corrections were applied to account for continued melting after the measurement dates.

are quantified from the differences between the observed and estimated ice thicknesses (Fig. 5). In this figure, the dashed line represents the 1-to-1 (i.e. $y=x$ ) perfect fit line, while the solid lines are those bracketing $95 \%$ of the data points (i.e. defining the $\pm 2 \sigma$ confidence interval, with $\sigma$ the standard deviation), which, in our case, correspond to angles of $30^{\circ}$ above and below the 1-to- 1 line. These lines are used for error projection, as follows: for a given thickness, the amplitude between the continuous lines (which equals $4 \sigma$ ) is used to estimate the corresponding standard error $\sigma$, which is then introduced into Eqs. (5), (3) and (4) to estimate the error in ice discharge. There is an RMSE of $103 \mathrm{~m}$ between the estimated and observed thickness data, indicating a poor fit. If

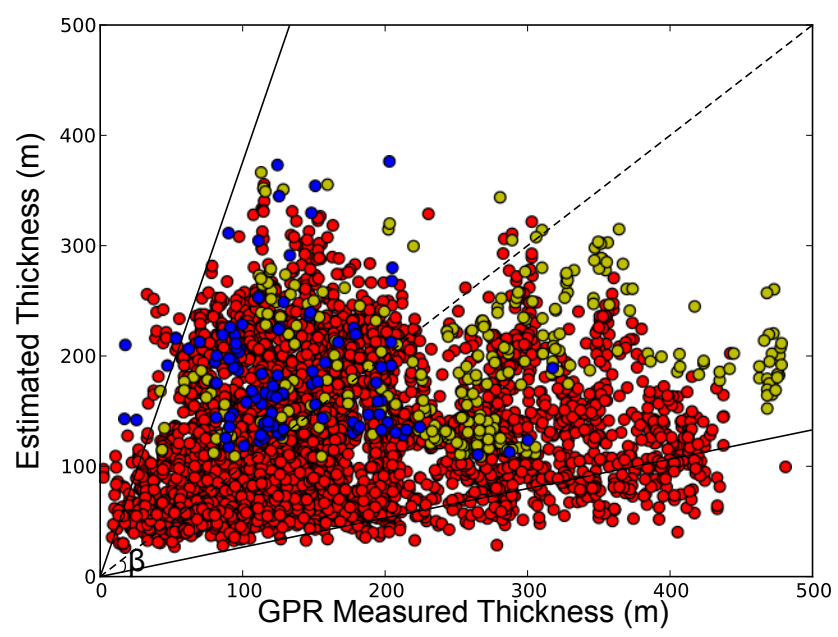

Figure 5. Measured vs. estimated ice thickness according to Eq. (5). The dashed line indicates the 1-to-1 line. Continuous lines show the $95 \%$ error boundary corresponding to $\beta=30^{\circ}$. Beta angle is used for error projections. Red, green and blue dots are used to distinguish points from the glacier regions with slow, medium and fast flow speeds, respectively.

the sharpened RAMP DEM is used instead of the combined DEM, this misfit increases to $109 \mathrm{~m}$, without any improvement in the data scatter, confirming that our combined DEM is the best choice.

For the winter and summer surface mass balances, we assume errors of $\pm 0.10 \mathrm{~m}$ w.e. $\mathrm{yr}^{-1}$ (Navarro et al., 2013). We assume the errors in frontal ablation and surface mass balance to be independent when computing the error of the total mass balance.

\section{Results}

\subsection{Surface velocities}

Average surface ice velocities obtained from SAR feature tracking are shown in Fig. 6. Spatially incoherent velocity measurements are masked out, and appear as white. Huron Glacier (7) shows the fastest flowing ice, with velocities up to $250 \mathrm{~m} \mathrm{yr}^{-1}$. Kaliakra (6), Perunika (21) and Charity (17) glaciers also show large surface velocities. Unfortunately, there are no in situ observations on any of these glaciers to which our remotely sensed velocities could be compared.

The temporal variations in ice velocities for each flux gate are shown in Fig. 7. The seasonality of these variations is approximated by fits to periodic curves. The data show large temporal variability. Although the scatter is large and the data density limited, velocities generally tend to be higher during summer than winter, as also indicated in some cases by a relatively high correlation coefficient. However, in other cases the fit is rather poor or even meaningless, indicating that the velocity variations do not follow a simple seasonal pattern, 


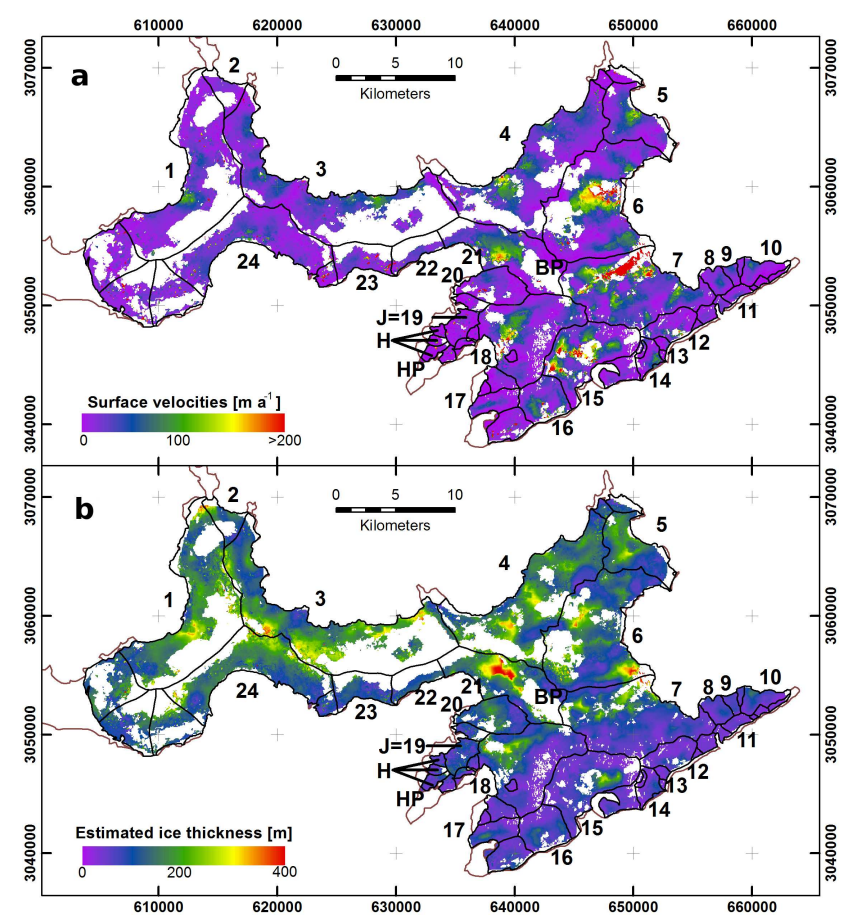

Figure 6. (a) Surface velocities obtained from SAR feature tracking. Huron Glacier (7) shows the fastest flow. (b) Estimated ice thickness computed from surface velocity using Eq. (5). The brown lines indicate the extent of the ice-free areas.

or the data density is insufficient, or uncertainties are too large to infer seasonal patterns. To explore a possible correlation of the velocity variations with air temperature, the figure also marks the periods of continuous daily mean temperatures above $0{ }^{\circ} \mathrm{C}$.

\subsection{Ice thickness}

The ice-thickness distribution estimated from the average surface velocities and the combined DEM (Fig. 3) using Eqs. (5) and (6) is shown in Fig. 6. The computed icethickness values are in the same range as the GPR measurements. However, the poor fit between the estimated and measured data sets indicates large errors (Fig. 5), as discussed further in Sect. 6.1.

The ice-thickness values obtained using our combined DEM and the sharpened RAMP DEM are very similar, with the exception of basin 2 (due to ICESat contributions) and, to a lesser extent, to the north-east of the island (due to TanDEM-X contributions), where these contributions helped to improve the results based on the combined DEM.

\subsection{Frontal ablation}

Frontal ablation rates for all investigated tidewater glaciers are given in Table 2. The largest rate is found for Huron Glacier (7, Fig. 2), followed by glacier basin 3. The total for all tidewater glaciers is $-509 \pm 263 \mathrm{Mtyr}^{-1}$. If the errors for the individual basins were considered independent and random, the error in total frontal ablation would be given by the root square of the sum of squares, which is $141 \mathrm{Mt} \mathrm{yr}^{-1}$. If, on the other hand, they were considered as linearly dependent, the error in total frontal ablation would be given by the sum of those of the individual basins, which is $381 \mathrm{Mt} \mathrm{yr}^{-1}$. Since these are the two extreme scenarios, and the errors of the individual basins are expected to be neither fully independent nor linearly dependent, we take the average of both extreme cases, $263 \mathrm{Mt} \mathrm{yr}^{-1}$, as the most likely error for the total ablation. The total frontal ablation of $-509 \pm 263 \mathrm{Mt} \mathrm{yr}^{-1}$ is equivalent to a specific mass change of $-0.85 \pm 0.44 \mathrm{~m}$ w.e. $\mathrm{yr}^{-1}$ over the total area of the analysed basins $\left(599 \mathrm{~km}^{2}\right)$ and $-0.73 \pm 0.38 \mathrm{~m}$ w.e. $\mathrm{yr}^{-1}$ over the area of the whole ice cap $\left(697 \mathrm{~km}^{2}\right)$.

We note that the ice discharge values for some basins could be slightly underestimated since velocity estimates were not available for the entire length of the flux gates. Hence these sections could not be considered in the flux calculation, leading to lower than expected discharge for these basins. This happens in particular for basin 7 , and to a lesser extent for basin 6 , where large velocities are observed up-glacier from the flux gate (see map of velocities in Fig. 6 and flux-gate locations in Fig. 2).

The changes in frontal ablation $\Delta D_{\text {seas }}$ for each basin, associated with the seasonal variations in surface velocity described earlier and characterized by their standard deviation $\sigma_{u \text { seas, }}$ are given in Table 2. The largest variation in frontal ablation occurs at basin 3 and is $43 \mathrm{Mt} \mathrm{yr}^{-1}$. In terms of specific units, the variations attain their highest value of $1.04 \mathrm{~m}$ w.e. $\mathrm{yr}^{-1}$ at basin 10 . The total variation of frontal ablation from all basins reaches $237 \mathrm{Mt} \mathrm{yr}^{-1}$, which is slightly smaller than the total uncertainty estimated for the frontal ablation $\left(263 \mathrm{Mt} \mathrm{yr}^{-1}\right)$ but is still considerable, as it is $46 \%$ of the best estimate for the frontal ablation $\left(-509 \mathrm{Mt} \mathrm{yr}^{-1}\right)$.

If the sharpened RAMP DEM is used instead of the combined DEM, the resulting total frontal ablation $\left(-521 \mathrm{Mt} \mathrm{yr}^{-1}\right)$ and its temporal variations $\left(234 \mathrm{Mt} \mathrm{yr}^{-1}\right)$ are very similar to those obtained using the combined DEM, with local differences between the results for both DEMs at the same basins as discussed for the ice thickness.

\subsection{Surface mass balance and total mass balance}

The gradient method discussed in Sect. 4.5 yields a mean glacier-wide winter balance and summer balance of $0.79 \pm$ 0.10 and $-0.73 \pm 0.10 \mathrm{mw}$.e. $\mathrm{yr}^{-1}$, respectively, for the mass-balance years $2007 / 2008$ to $2010 / 2011$. The resulting mean annual surface mass balance for the entire Livingston Island is $0.06 \pm 0.14 \mathrm{~m}$ w.e. $\mathrm{yr}^{-1}$, which, added to the contribution to mass balance by frontal ablation $(-0.73 \pm$ $0.38 \mathrm{~m}$ w.e. $\mathrm{yr}^{-1}$ ), gives a total mass balance for Livingston Island of $-0.67 \pm 0.40 \mathrm{~m}$ w.e. $\mathrm{yr}^{-1}$. 


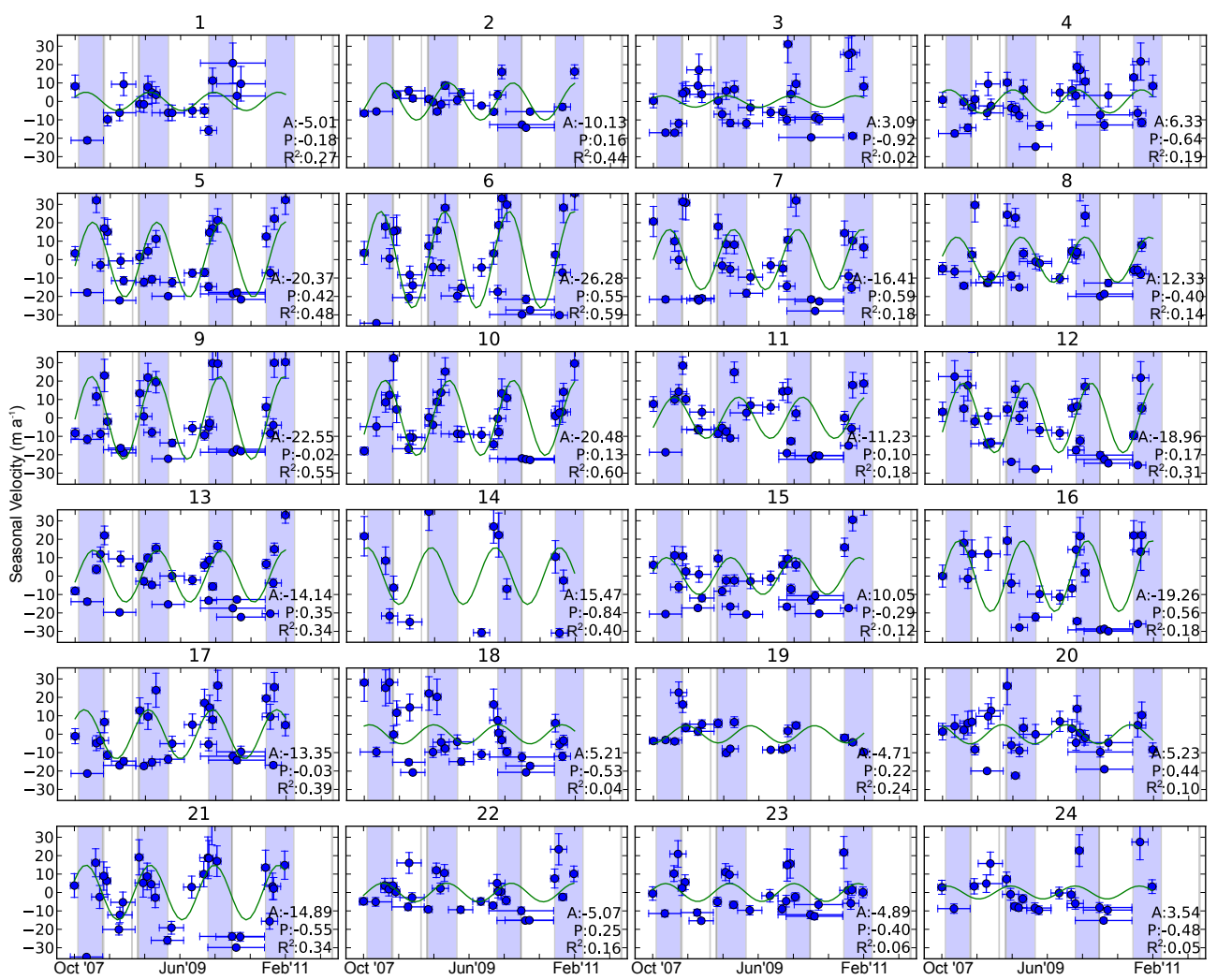

Figure 7. Detrended velocity time series for all analysed tidewater glaciers (see Fig. 2 for location of glaciers 1-24). Velocities are averaged over each glacier's flux gate and shown as deviations of each glacier's mean over the period October 2007-March 2011. Fits to a periodic signal and their amplitude $A$, phase $P$ (in partial years) and coefficient of determination $R^{2}$ are shown to illustrate the seasonality. Larger amplitudes indicate stronger seasonal effects. Continuous periods with daily air temperature exceeding $0{ }^{\circ} \mathrm{C}$ are shaded in blue, using the temperature records from Juan Carlos I weather station (12 m a.s.1., Fig. 1). Horizontal bars indicate the time interval of each measurement (temporal baseline).

\section{Discussion}

\subsection{Uncertainties}

The large discrepancies between the calculated and observed thicknesses shown in Fig. 5 (RMSE of $103 \mathrm{~m}$ ) indicate that our estimates of frontal ablation for Livingston Island should be considered only as a rough first-order approximation. The large errors result from a combination of those inherent to the estimation of surface velocities from PALSAR-1 images, those intervening in the conversion of surface velocity to thickness-averaged velocity using Eq. (3), and those involved in the retrieval of ice thickness from thickness-averaged velocity and surface slope using Eqs. (5) and (6). In our case, the latter are expected to be dominant. This error component encompasses both the limitations of the physical model and the choice of values for the model parameters.

The physical model represented by Eqs. (5) and (6) assumes deformation by simple shear, neglecting longitudinal stress gradients although these are known to be important near the calving fronts because of the large values of the along-flow gradient of the surface velocity. Consequently, the ice thickness inferred near the calving fronts, where the ice fluxes are computed, are expected to be poor, implying large errors in the ice discharge calculation. Using a single fit of the parameters $E$ and $f$ all over the Livingston ice cap, as done in Osmanoglu et al. (2013a) for the neighbouring King George Island ice cap, resulted in large RMSEs (rms misfits $>200 \mathrm{~m}$ ). Using separate fits for the regions of slow, medium and fast flow, as described in Sect. 5.2, allowed us to significantly reduce the error, though the current RMSE (103 m) is still very large. Individual RMSEs for glaciers with slow, medium and fast flow speed are 104, 117 and $70 \mathrm{~m}$, respectively, which represent 84,61 and $38 \%$ of the corresponding averages of the computed thickness values.

In Fig. 5, most of the data points with measured and computed ice thickness of similar magnitude correspond to the slow-moving glacier regions. For the slow-moving ice the data are scattered around the 1-to-1 line, though the computed ice thickness is clearly underestimated for measured ice thickness above $200 \mathrm{~m}$. The medium-flow glaciers are the thickest, with measurements reaching over $450 \mathrm{~m}$, and most of the points are scattered below the 1-to-1 line, indicating 
Table 2. Estimated frontal ablation rates $A_{\mathrm{f}}$ for the period between October 2007 and March 2011 (including the percentage of the ice cap's total frontal ablation), basin area (and its percentage of total area), and average thickness $\bar{H}$, length and average surface velocities $\bar{u}_{\text {sfc }}$ of the flux gates of all investigated tidewater glaciers on Livingston Island (Fig. 2). $\sigma_{u}$ seas is the standard deviation of the available velocities averaged over the flux gates and $\Delta D_{\text {seas }}$ is the associated variation in frontal ablation. Frontal ablation rates are given in Mt yr ${ }^{-1}$ and in specific units $\left(\mathrm{m}\right.$ w.e. $\mathrm{yr}^{-1}$ ). The temporal variations in velocity $\sigma_{u \text { seas }}$ are also expressed as a percentage of each flux gate's average velocity $\bar{u}_{\text {sfc }}$.

\begin{tabular}{|c|c|c|c|c|c|c|c|c|c|c|c|}
\hline \multirow[t]{2}{*}{ Basin } & \multicolumn{2}{|c|}{ Frontal ablation $A_{\mathrm{f}}$} & \multirow[b]{2}{*}{$\%$} & \multicolumn{2}{|c|}{ Area } & \multirow{2}{*}{$\begin{array}{l}\bar{H} \\
\mathrm{~m}\end{array}$} & \multirow{2}{*}{$\begin{array}{r}\text { Length } \\
\text { km }\end{array}$} & \multicolumn{2}{|c|}{$\bar{u}_{\mathrm{sfc}} \pm \sigma_{u \text { seas }}$} & \multicolumn{2}{|c|}{$\Delta D_{\text {seas }}$} \\
\hline & $\mathrm{Mt} \mathrm{yr}^{-1}$ & mw.e. $\mathrm{yr}^{-1}$ & & $\mathrm{~km}^{2}$ & $\%$ & & & $\mathrm{~m} \mathrm{yr}^{-1}$ & $\%$ & Mt yr $^{-1}$ & m w.e. $\mathrm{yr}^{-1}$ \\
\hline 1 & $-42.7 \pm 31.3$ & $-0.61 \pm 0.45$ & 8.4 & 69.6 & 11.6 & 180 & 16.8 & $29 \pm 10$ & 36 & 25.0 & 0.36 \\
\hline 2 & $-5.3 \pm 3.9$ & $-0.80 \pm 0.59$ & 1.0 & 6.7 & 1.1 & 127 & 3.7 & $16 \pm 8$ & 50 & 3.0 & 0.45 \\
\hline 3 & $-69.8 \pm 51.2$ & $-0.85 \pm 0.62$ & 13.7 & 82.1 & 13.7 & 172 & 22.7 & $24 \pm 14$ & 56 & 42.9 & 0.52 \\
\hline 4 & $-58.8 \pm 43.2$ & $-0.86 \pm 0.63$ & 11.6 & 68.3 & 11.4 & 153 & 18.1 & $26 \pm 11$ & 42 & 24.6 & 0.36 \\
\hline 5 & $-18.8 \pm 13.8$ & $-0.93 \pm 0.68$ & 3.7 & 20.3 & 3.4 & 154 & 7.7 & $27 \pm 17$ & 62 & 15.9 & 0.78 \\
\hline 6 (Kaliakra) & $-53.1 \pm 39.0$ & $-0.83 \pm 0.61$ & 10.4 & 64.3 & 10.7 & 167 & 10.6 & $37 \pm 21$ & 57 & 29.7 & 0.46 \\
\hline 7 (Huron) & $-145.4 \pm 114.1$ & $-2.69 \pm 2.11$ & 28.6 & 54.1 & 9 & 100 & 7.2 & $30 \pm 19$ & 64 & 11.2 & 0.21 \\
\hline 8 & $-0.7 \pm 0.5$ & $-0.15 \pm 0.11$ & 0.1 & 4.4 & 0.7 & 65 & 2.1 & $23 \pm 15$ & 67 & 1.7 & 0.39 \\
\hline 9 & $-1.3 \pm 0.9$ & $-0.74 \pm 0.54$ & 0.3 & 1.7 & 0.3 & 65 & 1.2 & $23 \pm 17$ & 75 & 1.1 & 0.65 \\
\hline 10 & $-4.8 \pm 3.5$ & $-0.90 \pm 0.66$ & 0.9 & 5.3 & 0.9 & 121 & 3.8 & $29 \pm 15$ & 52 & 5.5 & 1.04 \\
\hline 11 (Strandzha) & $-1.8 \pm 1.3$ & $-0.82 \pm 0.60$ & 0.3 & 2.2 & 0.4 & 54 & 2.1 & $23 \pm 14$ & 62 & 1.3 & 0.59 \\
\hline 12 (Dobrudzha) & $-4.1 \pm 3.0$ & $-0.48 \pm 0.35$ & 0.8 & 8.7 & 1.5 & 85 & 2.8 & $33 \pm 20$ & 60 & 3.8 & 0.44 \\
\hline 13 (Magura) & $-0.4 \pm 0.3$ & $-0.37 \pm 0.28$ & 0.1 & 1.1 & 0.2 & 52 & 1 & $24 \pm 14$ & 58 & 0.6 & 0.55 \\
\hline 14 (Srebarna) & $-4.8 \pm 3.5$ & $-1.07 \pm 0.78$ & 0.9 & 4.4 & 0.7 & 74 & 2.3 & $45 \pm 23$ & 50 & 3.1 & 0.70 \\
\hline 15 (Macy) & $-2.4 \pm 1.8$ & $-0.08 \pm 0.06$ & 0.5 & 30.1 & 5 & 71 & 3.4 & $26 \pm 17$ & 68 & 3.4 & 0.11 \\
\hline 16 (Prespa) & $-8.7 \pm 6.4$ & $-0.68 \pm 0.50$ & 1.7 & 12.7 & 2.1 & 82 & 3.5 & $32 \pm 23$ & 73 & 5.4 & 0.43 \\
\hline 17 (Charity) & $-1.0 \pm 0.7$ & $-0.15 \pm 0.11$ & 0.2 & 6.6 & 1.1 & 95 & 3.1 & $24 \pm 15$ & 62 & 3.4 & 0.52 \\
\hline 18 (Huntress) & $-15.2 \pm 11.2$ & $-0.37 \pm 0.27$ & 3.0 & 40.8 & 6.8 & 108 & 4.3 & $24 \pm 15$ & 62 & 5.7 & 0.14 \\
\hline 19 (Johnsons) & $-0.4 \pm 0.3$ & $-0.07 \pm 0.05$ & 0.1 & 5.3 & 0.9 & 121 & 2.1 & $11 \pm 9$ & 78 & 1.8 & 0.34 \\
\hline 20 & $-2.6 \pm 1.9$ & $-0.20 \pm 0.15$ & 0.5 & 13.2 & 2.2 & 141 & 3 & $25 \pm 11$ & 43 & 3.8 & 0.29 \\
\hline 21 (Perunika) & $-23.8 \pm 17.5$ & $-0.71 \pm 0.52$ & 4.7 & 33.7 & 5.6 & 169 & 6.2 & $36 \pm 18$ & 50 & 15.3 & 0.45 \\
\hline 22 & $-10.0 \pm 7.3$ & $-1.21 \pm 0.89$ & 2.0 & 8.3 & 1.4 & 132 & 5 & $19 \pm 9$ & 50 & 4.9 & 0.59 \\
\hline 23 & $-6.9 \pm 5.1$ & $-0.58 \pm 0.43$ & 1.4 & 11.8 & 2 & 120 & 4.8 & $22 \pm 11$ & 47 & 4.9 & 0.42 \\
\hline 24 & $-26.1 \pm 19.2$ & $-0.60 \pm 0.44$ & 5.1 & 43.7 & 7.3 & 152 & 13.8 & $22 \pm 11$ & 49 & 18.8 & 0.43 \\
\hline Total & $-509 \pm 263$ & $-0.85 \pm 0.44$ & 100 & 599.4 & 100 & & & & & 237 & 0.40 \\
\hline Entire ice cap & & $-0.73 \pm 0.38$ & & 697.3 & & & & & & & 0.34 \\
\hline
\end{tabular}

that the ice thicknesses are generally underestimated for these glaciers. Points from the fast-flowing glaciers indicate overestimated ice thickness for measured thickness below $200 \mathrm{~m}$, while underestimated for thickness above $200 \mathrm{~m}$.

Another limitation is the assumption of steady state in Eqs. (5) and (6). The assumption is necessary to infer an icethickness distribution from velocity and surface slope data alone, without available thinning rate data. On Livingston Island, surface elevation changes have only been studied on the Hurd Peninsula (Fig. 2) over the period 1957-2000 (Ximenis et al., 1999; Molina et al., 2007), showing an equivalent average mass change of $-0.23 \pm 0.10 \mathrm{~m}$ w.e. $\mathrm{yr}^{-1}$. Combined with observed front retreat on most of the ice cap during that period (Calvet et al., 1999), this suggests that the geometry of the ice cap was not stationary as of 2000. Even if the mass losses from Hurd Peninsula ice cap have approximately halved during the period 2002-2011 as compared with the previous decades (Navarro et al., 2013), the surface geometry needs some time to adjust to the changing mass budget. This, however, occurs faster in tidewater glaciers as compared to land-terminating glaciers, because the former have larger velocities.

\subsection{Sensitivity tests}

From Eqs. (5) and (6) it immediately follows that, for $n=3$ and $m=2$, the surface velocity scales with the model parameters (sliding factor $f$, stiffness parameter $B$, bed roughness $R$ and enhancement factor $E$ ), and with ice thickness $H$ and surface slope $\alpha$, according to

$u_{\mathrm{sfc}} \sim f, B^{-3}, E, R^{-2}, H^{6}, \alpha^{3}$ (for small $\alpha$ )

and, from Eqs. (3) and (4), that the ice discharge through the flux gates scales linearly with velocity, flux-gate length, ice thickness and density. However, Eq. (5) is used to invert for ice thickness from surface velocity and slope. Consequently, we focused our sensitivity analysis on exploring how variations in the model parameters, as well as variations in the input data (surface velocity and slope), affect the estimated ice thickness (Fig. 8). Each parameter or variable was varied 

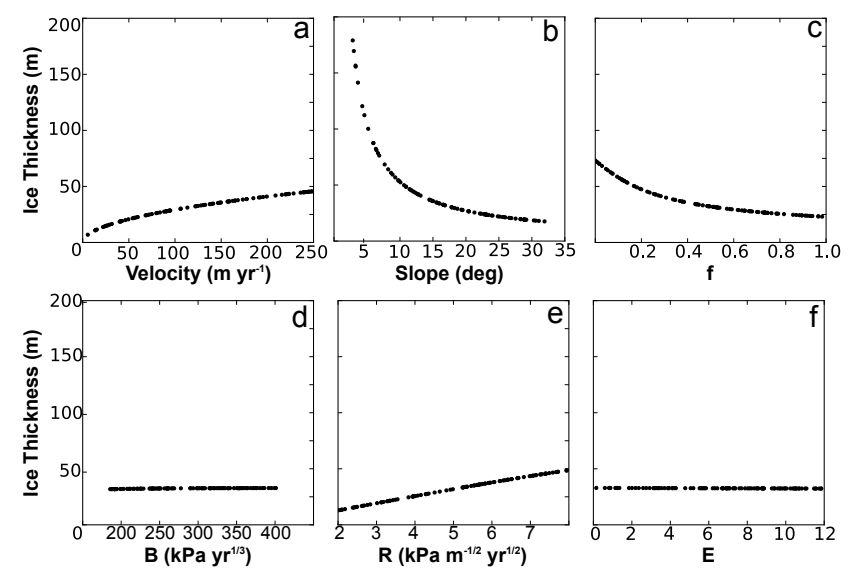

Figure 8. Sensitivity of computed ice thickness to model parameters and input data: computed ice thickness as a function of variations in (a) surface velocity, (b) surface slope $\alpha$, (c) sliding factor $f$, (d) stiffness parameter $B$, (e) bed roughness factor $R$ and (f) enhancement factor $E$ (see Eqs. 5 and 6).

within a predefined range of plausible values while all other parameters were assumed constant, and corresponding ice thickness was estimated using Eq. (5). Ice velocity (Eq. 5) was varied within the range of observed values (velocity) and surface slope (Eq. 6) from $1^{\circ}$ to its average value plus 3 standard deviations. For analysing a particular parameter or input data variable, we set all others to the median value of the range of variation shown in Fig. 8 .

Among the model parameters, the results for ice thickness are most sensitive to $f$ and $R$, while rather insensitive to $B$ and $E$. In our tuning of model parameters described in Sect. 4.4 we fixed the values of $B$ and $R$, because they are best constrained by observations, while we tuned the values of $f$ and $E$ (for the regions of slow, medium and fast flow separately) to minimize the misfit between computed and observed ice thickness. Consequently, the bed roughness $R$ remains as the model parameter to which our results are most sensitive. Concerning the sensitivity to variations in the input data, both velocity and surface slope have an important effect. Regarding velocities, the computed ice thickness is only moderately sensitive to velocity, though clearly more sensitive in the range of low velocities. However, since the errors in average velocity at the flux gates are relatively small, as shown in Fig. 7, our results are not expected to be much influenced by variations in input velocities. The surface slope, to which both ice thickness and flux are shown to be very sensitive, especially for low slope values, is therefore the largest source of uncertainty in our results.

\subsection{Temporal variations in surface velocities and associated changes in frontal ablation}

Noticeable temporal variations in surface velocities at the given flux gates are apparent from both Fig. 7 and the $\sigma_{u \text { seas }}$ values in Table 2. Surface velocities tend to be higher during summer $\left(30 \pm 17 \mathrm{~m} \mathrm{yr}^{-1}\right)$ than winter $\left(20 \pm 12 \mathrm{~m} \mathrm{yr}^{-1}\right)$. The quoted errors are the standard deviations of the measurements. Summer is defined by a year's longest continuous period, with air temperatures exceeding $0^{\circ} \mathrm{C}$ at Juan Carlos I meteorological station (Fig. 2). This suggests that enhanced summer velocities may be caused by surface melting and associated changes in the water supply to the glacier bed and resulting basal water pressure changes (e.g. Sugiyama et al., 2011). Clear seasonal variations are observed for several basins on Livingston Island. In particular, basins 6 (Kaliakra), 9 and 10, all located on the east side of the island, show large amplitudes, and the seasonal variations can be approximated reasonably well by the sinusoidal fit as indicated by coefficients of determination $\left(R^{2}\right)$ between 0.55 and 0.6 . Since these measurements are averaged along 10 parallel flux gates for each basin and for each image pair used in this analysis, it is very unlikely that these variations could arise from an error in our analysis.

However, for other basins, seasonal variations are less obvious with occasional increased velocities during the winter season. Occasional periods of surface melting and liquid precipitation events during the winter are not unusual in this region, which could imply basal water pressure changes and associated speed-up events.

In other cases a seasonality in velocity is evident (e.g. basins 11 and 14) but the correlation coefficient for the sinusoidal fit is poor. This indicates that the seasonality is not captured well by the highly simplistic sinusoidal fit. In these cases the amplitude and phase of the velocity seasonality seem to vary from year to year (e.g. basins 14 and 21).

Independent of their fit to the sinusoidal variation, the largest temporal variations in velocity correspond to the fastest flowing basins: basins 6 and 7 to the east and basins 12,14 and 16 to the south; the latter are small basins with large velocities due to large surface slopes. Basin 21 also shows both large average velocity and temporal variations. There is no clear relationship with other variables such as basin area or average ice thickness at the flux gate.

Regardless of the underlying mechanism for the temporal variations in surface velocity, these variations exert a direct influence on the frontal ablation rates, as shown in Table 2. The group of basins to the northern and north-eastern parts of the island (1-6), most of them having large frontal ablation rates, shows consistently large seasonal changes in frontal ablation (see $\Delta D_{\text {seas }}$ in Table 2). The sum of the seasonal changes of analysed basins corresponds to $46 \%$ of the total frontal ablation for the entire Livingston Island ice cap. Overall, the seasonality in ice velocities and frontal ablation rates stresses the importance to account for these variations when computing frontal ablation. 


\subsection{Frontal ablation}

The only available detailed estimate of mass losses due to frontal ablation on Livingston ice cap is that of Johnsons Glacier (19 in Fig. 2). Using a full-Stokes dynamical model constrained by measured velocities near the calving front, Navarro et al. (2013) calculated a frontal ablation of $-0.74 \pm 0.17 \mathrm{Mt} \mathrm{yr}^{-1}$ averaged over the period May 2004August 2007. This estimate compares reasonably well with our estimated value of $-0.4 \pm 0.3 \mathrm{Mtyr}^{-1}$ for the period 2008-2011 (Table 2).

Our ice-cap-wide frontal ablation estimate for Livingston Island is consistent with the results from a similar study on neighbouring King George Island. Osmanoglu et al. (2013a) estimated that King George Island $\left(1127 \mathrm{~km}^{2}\right)$ lost $720 \pm$ $428 \mathrm{Mtyr}^{-1}$ during the period January 2008-March 2011. The corresponding specific frontal ablation rate of $-0.64 \pm$ $0.38 \mathrm{~m}$ w.e. $\mathrm{yr}^{-1}$ is similar to Livingston's rate of $-0.73 \pm$ $0.38 \mathrm{~m}$ w.e. $\mathrm{yr}^{-1}$. We note that, in Osmanoglu et al. (2013a), the error in total frontal ablation was computed assuming that those of the individual basins were linearly dependent, and thus errors were simply added to yield the error for the entire ice cap. If done similarly for Livingston Island, the error for the specific rate would have been larger $\left( \pm 0.57 \mathrm{~m}\right.$ w.e. $\left.\mathrm{yr}^{-1}\right)$. The lower relative error of the estimate for King George Island is mostly due to wider coverage of GPR ice-thickness observations. On Livingston Island, many of the available ice-thickness measurements, mostly close to the ice divides in the western part of the ice cap, could not be used for the tuning of model parameters because ice velocities could not be derived from SAR data in these areas.

Our ice-cap-wide frontal ablation estimate is in the range of the ice discharge estimates for individual glaciers after the collapse of the Larsen B Ice Shelf and resulting dynamic adjustments, e.g. Evans Glacier $\left(459 \mathrm{Mt} \mathrm{yr}^{-1}, 2008\right)$ or Jorum Glacier main branch (534 $\mathrm{Mtyr}^{-1}, 2008$ ) (Rott et al., $2011)$, though the specific rates for these glaciers $(-2.19$ and $-1.68 \mathrm{mw}$ w.e. $\mathrm{yr}^{-1}$, respectively) are $2-3$ times larger than that of Livingston Island. Except for Columbia Glacier in Alaska (O'Neel et al., 2005), estimates in specific units are considerably higher for King George Island and Livingston Island ice caps than those reported for glaciers in the Arctic (AMAP, 2011).

\subsection{Approximate partitioning of total ablation into surface and frontal ablation}

Our independent estimates of frontal ablation and surface mass balance allow us to quantify the average partitioning of total annual ablation for the period 20072011. We assume that the derived summer balance is equal to total surface ablation, i.e. that summer snow accumulation is negligible. With the limitations inherent to the large errors in the frontal ablation estimates, we find that frontal ablation $\left(-0.73 \pm 0.38 \mathrm{mw}\right.$ we. $\left.\mathrm{yr}^{-1}\right)$ and surface ablation $\left(-0.73 \pm 0.10 \mathrm{~m}\right.$ w.e. $\left.\mathrm{yr}^{-1}\right)$ contribute similar shares to the total annual ablation $\left(-1.46 \pm 0.39 \mathrm{mw}\right.$.e. $\left.\mathrm{yr}^{-1}\right)$ of Livingston ice cap. Hence, total net mass change $\left(\delta M=-0.67 \pm 0.40 \mathrm{~m}\right.$ w.e. $\left.\mathrm{yr}^{-1}\right)$ is strongly negative despite a slightly positive surface mass balance $(0.06 \pm$ $0.14 \mathrm{~m}$ w.e. $\mathrm{yr}^{-1}$ ). Total specific net mass loss for Livingston Island ice cap is almost double the global average for all glaciers other than the ice sheets for the period 2003-2009 (Gardner et al., 2013).

Livingston ice cap's $50 \%$ contribution of frontal ablation to the total ablation is even larger than that of Arctic ice caps such as the Academy of Sciences Ice Cap, in Severnaya Zemlya (Dowdeswell et al., 2002), and Austonna, in Svalbard (Dowdeswell et al., 2008), which show contributions of frontal ablation to the total ablation of 30-40\%. Other studies in the Arctic region have also calculated the frontal ablation, but have presented their results as a percentage of the net mass changes (i.e. the sum of accumulation and ablation). For instance, Burgess et al. (2005) compared the total volume of ice lost due to calving with net mass loss from Devon Ice Cap between 1960 and 1999 estimated by Burgess and Sharp (2004), concluding that iceberg calving may account for up to $30 \%$ of the total net mass loss over that period. Similarly, Burgess et al. (2013) estimated regional calving losses of $17.1 \mathrm{Gt} \mathrm{yr}^{-1}$, over the period 2007-2011, for central Alaskan glaciers, which is equivalent to $36 \%$ of the region's total annual net mass change. We emphasize that computing the share of frontal ablation to total ablation (which is always a mass loss) is very different from computing the share with respect to the net mass change (which can be either gains or losses). The former approach requires that the partitioning of the budget between total (and not net) mass gains and losses is known.

\section{Conclusions}

Surface ice velocities derived for Livingston ice cap from feature tracking based on 25 SAR images acquired between October 2007 and March 2011 reveal several fast-flowing outlet glaciers reaching velocities of $250 \mathrm{~m} \mathrm{yr}^{-1}$. The ice velocities analysed across flux gates close to the calving fronts of the ice cap's tidewater glaciers reveal large inter-annual and seasonal variations. Although high values are occasionally observed during the winter and a clear seasonality is not apparent in all basins, velocities tend to be higher during the summer. This suggests that changes in basal water pressure, associated with either strong surface melting or rainfall events (which sometimes occur during the winter), are likely the main drivers of the temporal variations in surface velocity, but further studies are needed to explore the causes of the observed temporal variations in ice velocities.

The derived ice velocities were used in conjunction with estimates of ice thickness to approximate rates of frontal ablation of all tidewater glaciers. The ice cap on 
Livingston Island has lost on average (2007-2011) a total of $509 \pm 263 \mathrm{Mt} \mathrm{yr}^{-1}$ through ice discharge into the ocean, which is equivalent to a specific mass balance of $-0.73 \pm$ $0.38 \mathrm{~m}$ w.e. $\mathrm{yr}^{-1}$ calculated over the entire ice-covered area of $697 \mathrm{~km}^{2}$. This rate is similar to the one obtained on neighbouring King George Island (Osmanoglu et al., 2013a). Although both studies suffer from the lack of detailed icethickness observations, and hence include large uncertainties, these results indicate that frontal ablation may be a substantial component in the mass budget of glaciers in this region. To ascertain results, it is essential that accurate icethickness observations become available to reduce the uncertainties in estimates of frontal ablation based on a flux-gate approach.

Extrapolating surface mass-balance observations on two of the ice cap's glaciers over the entire ice cap indicates that the surface annual mass balance is slightly positive $\left(0.06 \pm 0.14 \mathrm{mw}^{\mathrm{m}}\right.$.e. $\left.\mathrm{yr}^{-1}\right)$, but total net mass change is considerably negative $\left(-0.67 \pm 0.40 \mathrm{mw}^{\mathrm{e}} \mathrm{e} \mathrm{yr}^{-1}\right)$ due to the mass losses through frontal ablation. Surface ablation $\left(-0.73 \pm 0.10 \mathrm{mw}\right.$.e. $\left.\mathrm{yr}^{-1}\right)$ and frontal ablation contribute similar shares to total ablation.

Frontal ablation varies by $46 \%$ of the estimated frontal ablation due to the observed interannual and seasonal velocity variations. This stresses the importance of taking into account temporal variations in ice velocity when computing frontal ablation with a flux-gate approach.

Author contributions. B. Osmanoglu led the development of the study and performed all frontal ablation calculations. M. Braun and R. Hock initiated the study. B. Osmanoglu, F. J. Navarro and R. Hock wrote the paper. F. J. Navarro, and M. I. Corcuera provided the surface mass balances and GPR data. M. Braun created most maps. All authors contributed to the discussion and interpretation of results.

Acknowledgements. Funding was provided by NSF project \#ANT1043649, NASA project \#NNX11A023G, DFG \#BR2105/9-1 and the National Plan of R\&D (Spain) project CTM2011-28980. We are grateful for the support provided through the ESF ERANET Europolar IMCOAST project (BMBF award AZ 03F0617B) and EU FP7-PEOPLE-2012-IRSES IMCONet grant 318718, as well as the Alaska Satellite Facility for data provision.

Edited by: J. L. Bamber

\section{References}

AMAP: Snow, Water Ice and Permafrost in the Arctic (SWIPA): Climate Change and the Cryosphere, vol. xii, Arctic Monitoring and Assesment Programme (AMAP), Oslo, Norway, 2011.

Balik, F., Alkis, A., Kurucu, Y., and Alkis, Z.: Validation of radargrammetric DEM generation from radarsat images in high relief areas in Edremit region of Turkey, in: XXth ISPRS Congress Technical Commission II, vol. XXXV, Istanbul, Turkey, 150 155, 2004.

Balz, T., He, X., Zhang, L., and Liao, M.: TerraSAR-X stereo radargrammetry for precise DEM generation in South-East Asia, in: Proceedings of Asian Conference on Remote Sensing, 2009.

Balz, T., Zhang, L., and Liao, M.: Direct stereo radargrammetric processing using massively parallel processing, ISPRS J. Photogramm., 79, 137-146, 2013.

Bamber, J. and Gomez-Dans, J. L.: The accuracy of digital elevation models of the Antarctic continent, Earth Planet. Sci. Lett., 237, 516-523, 2005.

Berardino, P., Fornaro, G., Lanari, R., and Sansosti, E.: A new algorithm for surface deformation monitoring based on small baseline differential SAR Interferograms, IEEE T. Geosci. Remote, 40, 2375-2383, doi:10.1109/TGRS.2002.803792, 2002.

Bliss, A., Hock, R., and Cogley, J. G.: A new inventory of mountain glaciers and ice caps for the Antarctic periphery, Ann. Glaciol., 54, 191-199, 2013.

Burgess, D. O. and Sharp, M. J.: Recent changes in areal extent of the Devon ice cap, Nunavut, Canada, Arct. Antarc. Alp. Res., 36, 261-271, 2004.

Burgess, D. O., Sharp, M. J., Mair, D. W. F., Dowdeswell, J. A., and Benham, T. J.: Flow dynamics and iceberg calving rates of Devon Ice Cap, Nunavut, Canada, J. Glaciol., 51, 219-230, 2005.

Burgess, D. O., Forster, R. R., and Larsen, C. F.: Flow velocities of Alaskan glaciers, Nat. Commun., 4, 51, doi:10.1038/ncomms3146, 2013.

Calvet, J., García Sellés, D., and Corbera, J.: Fluctuaciones de la extensión del casquete glacial de la isla Livingston (Shetland del Sur) desde 1956 hasta 1996, Acta geológica hispánica, 34, 365374, 1999.

Chen, C. W. and Zebker, H. A.: Two-dimensional phase unwrapping with use of statistical models for cost functions in nonlinear optimization, J. Opt. Soc. Am. A, 18, 338-351, 2001.

Cogley, J. G., Hock, R., Rasmussen, L. A., Arendt, A. A., Bauder, A., Braithwaite, R. J., Jansson, P., Kaser, G., Möller, M., Nicholson, L., and Zemp, M.: Glossary of Glacier Mass Balance and Related Terms, Technical Documents in Hydrology No. 86, UNESCO-IHP, Paris, 2011.

Cuffey, K. M. and Paterson, W. S. B.: The Physics of Glaciers, 4th Edn., Elsevier, Amsterdam, 693 pp., 2010.

DOS: British Antarctic Territory, South Shetland Islands, Sheet W 62 60, Scale 1 : 200 000, D.O.S. 610 (Series D501), Pub. Directorate of Overseas Surveys, 1968.

Dowdeswell, J. A., Bassford, R. P., Gorman, M. R., Williams, M., Glazovsky, A. F., Macheret, Y. Y., Shepherd, A. P., Vasilenko, Y. V., Savatyuguin, L. M., Hubberten, H.-W., and Miller, H.: Form and flow of the Academy of Sciences Ice Cap, Severnaya Zemlya, Russian High Arctic, J. Geophys. Res., 107, 2076 , doi:10.1029/2000JB000129, 2002. 
Dowdeswell, J. A., Benham, T., Strozzi, T., and Hagen, J.: Iceberg calving flux and mass balance of the Austfonna ice cap on Nordaustlandet, Svalbard, J. Geophys. Res., 113, F03022, doi:10.1029/2007JF000905, 2008.

Eineder, M.: Efficient simulation of SAR Interferograms of large areas and of rugged terrain, IEEE T. Geosci. Remote, 41, 14151427, 2003.

Gardner, A. S., Moholdt, G., Cogley, J. G., Wouters, B., Arendt, A. A., Wahr, J., Berthier, E., Hock, R., Pfeffer, W. T., Kaser, G., Ligtenberg, S. R. M., Bolch, T., Sharp, M. J., Hagen, J. O., van den Broeke, M. R., and Paul, F.: A reconciled estimate of glacier contributions to sea level rise: 2003 to 2009, Science, 340, 852-857, doi:10.1126/science.1234532, 2013.

Giesen, R. H. and Oerlemans, J.: Climate-model induced differences in the 21 st century global and regional glacier contributions to sea-level rise, Clim. Dynam., 41, 3283-3300, doi:10.1007/s00382-013-1743-7, 2013.

Gonzalez, J. H., Bachmann, M., Krieger, G., and Fiedler, H.: Development of the TanDEM-X calibration concept: analysis of systematic errors, IEEE T. Geosci. Remote, 48, 716-726, 2010.

Gray, A., Mattar, K., Vachon, P., Bindschadler, R., Jezek, K., Forster, R., and Crawford, J.: InSAR results from the RADARSAT Antarctic Mapping Mission data: estimation of glacier motion using a simple registration procedure, in: Geoscience and Remote Sensing Symposium Proceedings, 1998, IGARSS'98, 1998 IEEE International, vol. 3, 1638-1640, 1998.

Greve, R. and Blatter, H.: Dynamics of Ice Sheets and Glaciers, Springer-Verlag, Berlin, Heidelberg, 302 pp., 2009.

Hengl, T. and Reuter, H.: How accurate and usable is GDEM?, a statistical assessment of GDEM using LiDAR data, Geomorphometry, 2, 45-48, 2011.

Hirt, C., Filmer, M., and Featherstone, W.: Comparison and validation of recent freely-available Aster-Gdem Ver1, SRTM Ver4. 1 And Geodata DEM-9S Ver3 Digital Elevation Models Over Australia, Aust. J. Earth Sci., 57, 337-347, 2010.

Hock, R., de Woul, M., Radić, V., and Dyurgerov, M.: Mountain glaciers and ice caps around Antarctica make a large sea-level rise contribution, Geophys. Res. Lett., 36, L07501, doi:10.1029/2008GL037020, 2009.

IPCC 2013: Summary for Policymakers, in: Climate Change 2013: The Physical Science Basis, Working Group I Contribution to the Fifth Assessment Report of the Intergovernmental Panel on Climate Change, edited by: Stocker, T. F., Qin, D., Plattner, G.-K., Tignor, M., Allen, S. K., Boschung, J., Nauels, A., Xia, Y., Bex, V., and Midgley, P. M., Cambridge University Press, Cambridge, UK and New York, NY, USA, 27 pp., 2013.

Jonsell, U. Y., Navarro, F. J., Bañón, M., Lapazaran, J. J., and Otero, J.: Sensitivity of a distributed temperature-radiation index melt model based on AWS observations and surface energy balance fluxes, Hurd Peninsula glaciers, Livingston Island, Antarctica, The Cryosphere, 6, 539-552, doi:10.5194/tc-6-539-2012, 2012.

Korona, J., Berthier, E., Bernard, M., Rémy, F., and Thouvenot, E.: SPIRIT. SPOT 5 stereoscopic survey of Polar Ice: Reference Images and Topographies during the fourth International Polar Year (2007-2009), ISPRS J. Photogramm., 64, 204-212, 2009.

Krieger, G., Moreira, A., Fiedler, H., Hajnsek, I., Werner, M., Younis, M., and Zink, M.: TanDEM-X: A Satellite Formation for High-Resolution SAR Interferometry, IEEE T. Geosci. Remote, 45, 3317-3341, 2007.
Lanari, R., Casu, F., Manzo, M., Zeni, G., Berardino, P., Manunta, M., and Pepe, A.: An overview of the small baseline subset algorithm: a DInSAR technique for surface deformation analysis, Pure Appl. Geophys., 164, 637-661, 2007.

Liu, H., Jezek, K., Li, B., and Zhao, Z.: Radarsat Antarctic Mapping Project digital elevation model version 2. Boulder, CO: National Snow and Ice Data Center, Digital media, available at: http://nsidc.org/data/nsidc-0082.html (last access: 12 September 2014), 2001.

Macheret, Y., Otero, J., Navarro, F., Vasilenko, E., Corcuera, M., Cuadrado, M., and Glazovsky, A.: Ice thickness, internal structure and subglacial topography of Bowles Plateau ice cap and the main ice divides of Livingston Island, Antarctica, by groundbased radio-echo sounding, Ann. Glaciol., 50, 49-56, 2009.

Magruder, L. A., Webb, C. E., Urban, T. J., Silverberg, E. C., and Schutz, B. E.: ICESat altimetry data product verification at White Sands Space Harbor, IEEE T. Geosci. Remote, 45, 147-155, 2007.

Marzeion, B., Jarosch, A. H., and Hofer, M.: Past and future sealevel change from the surface mass balance of glaciers, The Cryosphere, 6, 1295-1322, doi:10.5194/tc-6-1295-2012, 2012.

Mittermayer, J., Schattler, B., and Younis, M.: Terrasar-X Commissioning Phase Execution and Results, in: Geoscience and Remote Sensing Symposium, 2008, IGARSS 2008, IEEE International, vol. 2, pp. 197-200, IEEE, doi:10.1109/IGARSS.2008.4778961, 2008.

Molina, C., Navarro, F., Calvet, J., Garcia-Selles, D., and Lapazaran, J.: Hurd Peninsula glaciers, Livingston Island, Antarctica, as indicators of regional warming: ice-volume changes during the period 1956-2000, Ann. Glaciol., 46, 43-49, 2007.

Navarro, F., Otero, J., Macheret, Y., Vasilenko, E., Lapazaran, J., Ahlstrom, A., and Machio, F.: Radioglaciological studies on Hurd Peninsula glaciers, Livingston Island, Antarctica, Ann. Glaciol., 50, 17-24, 2009.

Navarro, F., Jonsell, U., Corcuera, M., and Martín-Español, A.: Decelerated mass loss of Hurd and Johnsons glaciers, Livingston Island, Antarctic Peninsula, J. Glaciol., 59, 115-128, 2013.

O’Neel, S., Pfeffer, W., Krimmel, R., and Meier, M.: Evolving force balance at Columbia Glacier, Alaska, during its rapid retreat, J. Geophys. Res, 110, F03012, doi:10.1029/2005JF000292, 2005.

Orheim, O. and Govorukha., L.: Present-day glaciation in the South Shetland Islands, Ann. Glaciol., 3, 233-238, 1982.

Osmanoglu, B., Braun, M., Hock, R., and Navarro, F.: Surface velocity and ice discharge of the ice cap on King George Island, Antarctica, Ann. Glaciol., 54, 111-119, $2013 \mathrm{a}$.

Osmanoglu, B., Dixon, T., and Wdowinski, S.: 3-D phase unwrapping for satellite radar interferometry, I: DEM generation, International Archives of the Photogrammetry, Remote Sensing and Spatial Information Sciences, Volume XL-7/W2, ISPRS2013-SSG, 11-17 November 2013, Antalya, Turkey, doi:10.5194/isprsarchives-XL-7-W2-185-2012013, 2013b.

Osmanoglu, B., Dixon, T. H., Wdowinski, S., and Cabral-Cano, E.: On the importance of Path for Phase Unwrapping in Synthetic Aperture Radar Interferometry, Appl. Optics, 50, 3205-3220, doi:10.1364/AO.50.003205, 2011.

Otero, J.: Generación automática de malla de elementos finitos en modelos evolutivos de dinámica de glaciares, Ph.D. thesis, Universidad Politécnica de Madrid, ETSI de Caminos, Canales y Puertos, 2008. 
Otero, J., Navarro, F., Martin, C., Cuadrado, M., and Corcuera, M.: A three-dimensional calving model: numerical experiments on Johnsons Glacier, Livingston Island, Antarctica, J. Glaciol., 56, 200-214, 2010

Pfeffer, T., Arendt, A., Bliss, A., Bolch, T., Cogley, J. G., Gardner, A. S., Hagen, J. O., Hock, R., Kaser, G., Kienholz, C., Miles, E. S. Moholdt, G., Moelg, N., Paul, F., Radić, V., Rastner, P., Raup, B. H., Rich, J., Sharp, M. J., and the Randolph Consortium: The Randolph Glacier Inventory: a globally complete inventory of glaciers, J. Glaciol., 60, 537-552, 2014.

Radić, V., Bliss, A., Beedlow, A. C., Hock, R., Miles, E., and Cogley, J. G.: Regional and global projections of twenty-first century glacier mass changes in response to climate scenarios from global climate models, Clim. Dynam., 42, 37-58, doi:10.1007/s00382-013-1719-7, 2013.

Radić, V. and Hock, R.: Regionally differentiated contribution of mountain glaciers and ice caps to future sea-level rise, Nat. Geosci., 4, 91-94, doi:10.1038/NGEO1052, 2011.

Raper, S. C. and Braithwaite, R. J.: Low sea level rise projections from mountain glaciers and icecaps under global warming, Nature, 439, 311-313, 2006.

Rees, W. G.: Remote sensing of snow and ice, CRC Press, Taylor and Francis Group, Boca Raton, Florida, 285 pp., 2006.

Reuter, H., Nelson, A., Strobl, P., Mehl, W., and Jarvis, A.: A first assessment of Aster Gdem Tiles for absolute accuracy, relative accuracy and terrain parameters, in: Geoscience and Remote Sensing Symposium, 2009 IEEE International, IGARSS 2009, vol. 5, V-240, 2009.

Rignot, E.: Mapping of glacial motion and surface topography of Hielo Patagonico Norte, Chile, using satellite SAR L-band interferometry data, Ann. Glaciol., 23, 209-216, 1996.

Rosenqvist, A., Shimada, M., Ito, N., and Watanabe, M.: ALOS PALSAR: A Pathfinder Mission for Global-Scale Monitoring of the Environment, IEEE T. Geosci. Remote, 45, 3307-3316, 2007.

Rott, H., Müller, F., Nagler, T., and Floricioiu, D.: The imbalance of glaciers after disintegration of Larsen-B ice shelf, Antarctic Peninsula, The Cryosphere, 5, 125-134, doi:10.5194/tc-5-1252011, 2011.

SGE: Spanish Antarctic Cartography, Livingston and Deception Islands, scale $1: 100$ 000, 1st Edn. Pub., Servicio Geográfico del Ejército, 1997.
Shepherd, A., Ivins, Geruo, A., Barletta, V. R., Bentley, M. J., Bettadpur, S., Briggs, K. H., Bromwich, D. H., Forsberg, R., Galin, N., Horwath, M., Jacobs, S., Joughin, I., King, M. A., Lenaerts, J. T. M., Li, J., Ligtenberg, S. R. M., Luckman, A., Luthcke, S. B., McMillan, M., Meister, R., Milne, G., Mouginot, J., Muir, A., Nicolas, J. P., Paden, J., Payne, A. J., Pritchard, H., Rignot, E., Rott, H., Sandberg Sørensen, L., Scambos, T. A., Scheuchl, B., Schrama, E. J. O., Smith, B., Sundal, A. V., van Angelen, J. H., van de Berg, W. J., van den Broeke, M. R., Vaughan, D. G., Velicogna, I., Wahr, J., Whitehouse, P. L., Wingham, D. J., Yi, D., Young, D., and Zwally, H. J.: A reconciled estimate of ice-sheet mass balance, Science, 338, 1183-1189, doi:10.1126/science.1228102, 2012.

Slangen, A., Katsman, C., van de Wal, R., Vermeersen, L., and Riva, R.: Towards regional projections of twenty-first century sea-level change based on IPCC SRES scenarios, Clim. Dynam., 38, 1191-1209, doi:10.1007/s00382-011-1057-6, 2012.

Steig, E. J. and Orsi, A. J.: Climate science: the heat is on in Antarctica, Nat. Geosci., 6, 87-88, 2013.

Strozzi, T., Luckman, A., Murray, T., Wegmuller, U., and Werner, C.: Glacier motion estimation using SAR offset-tracking procedures, IEEE T. Geosci. Remote, 40, 2384-2391, 2002.

Strozzi, T., Kouraev, A., Wiesmann, A., Wegmüller, U., Sharov, A., and Werner, C.: Estimation of Arctic glacier motion with satellite L-band SAR data, Remote Sens. Environ., 112, 636-645, 2008.

Sugiyama, S., Skvarca, P., Naito, N., Enomoto, H., Tsutaki, S., Tone, K., Marinsek, S., and Aniya, M.: Ice speed of a calving glacier modulated by small fluctuations in basal water pressure, Nat. Geosci., 4, 597-600, doi:10.1038/ngeo1218, 2011.

Turner, J., Barrand, N. E., Bracegirdle, T. J., Convey, P., Hodgson, D. A., Jarvis, M., Jenkins, A., Marshall, G., Meredith, M. P., Roscoe, H., Shanklin, J., French, J., Goosse, H., Guglielmin, M., Gutt, J., Jacobs, S., Kennicutt, M. C. I., Masson-Delmotte, V., Mayewski, P., Navarro, F., Robinson, S., Scambos, T., Sparrow, M., Summerhayes, C., Speer, K., and Klepikov, A.: Antarctic climate change and the environment: an update, Polar Rec., 1-23, doi:10.1017/S0032247413000296, 2013.

Werner, C., Wegmuller, U., Strozzi, T., and Wiesmann, A.: Precision estimation of local offsets between pairs of SAR SLCs and detected SAR images, in: Geoscience and Remote Sensing Symposium, 2005, IGARSS'05, Proceedings, 2005 IEEE International, vol. 7, 4803-4805, 2005.

Ximenis, L., Calvet, J., Enrique, J., Corbera, J., Fernández de Gamboa, C., and Furdada i Bellavista, G.: The measurement of ice velocity, mass balance and thinning-rate on Johnsons Glacier, Livingston Island, South Shetland Islands, Antarctica, Acta Geológica Hispánica, 34, 406-409, 1999. 